
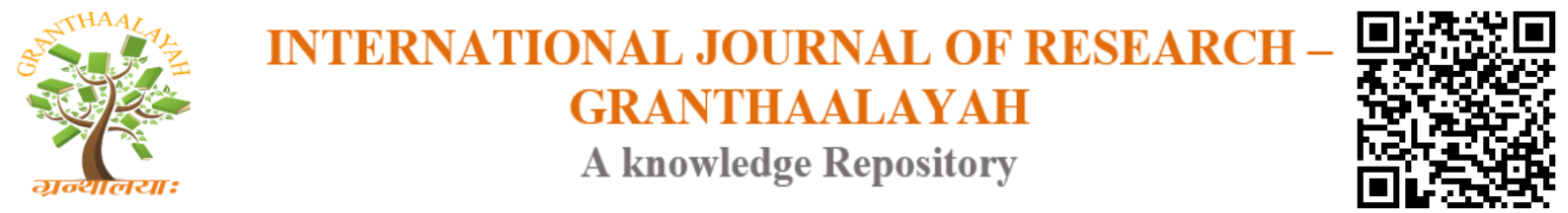

Management

\title{
DETECTING EARNINGS MANAGEMENT INVESTIGATION ON DIFFERENT MODELS MEASURING EARNINGS MANAGEMENT FOR EMERGING EASTERN EUROPEAN COUNTRIES
}

\author{
Susana Callao ${ }^{1}$, José I. Jarne ${ }^{2}$, David Wróblewski ${ }^{* 3}$ \\ ${ }^{1}$ Lecturer in Accounting, University of Zaragoza, Faculty of Economy and Business, Spain \\ ${ }^{2}$ Jarne, José I., Lecturer in Accounting, University of Zaragoza, Faculty of Economy and \\ Business, Spain \\ ${ }^{* 3}$ Doctor in Accounting and Finance, Associate Professor of University of Zaragoza, Spain
}

\begin{abstract}
Earnings management has received considerable attention as numerous papers were investigated different hypotheses. However, there is still no consensus on how efficiently detect and measure earnings managements. Nevertheless, most authors use methodology based on accruals, sophisticated models that attempt to separate total accruals into discretionary and nondiscretionary components. We may find wide range of use of alternative models to measure earnings management. Nevertheless, the researchers typically used five the most popular models: the Jones (1991) model, the modified Jones model (Dechow, Sloan, and Sweeney, 1995), Teoh, Welch and Wong (1998) model, Kasznik (1999) model and Kothari et al. (2005) model. However, it is confirmed that the environment where the company is operating influences on the earnings management.

Therefore, we focus our study on the growing market of the developing European countries. In particular, our analysis comprises four different and independent samples from emerging Eastern European countries: Poland, Hungary, Slovakia and the Czech Republic, since earnings management in Eastern European countries is still barely explored. Consequently, our objective is to evaluate the ability of the existing models on earnings management for the environment of countries from the East of Europe.

Our results confirm that the Jones (1991), Shivakumar (1996), Kasznik (1999) and Yoon and Miller model (2002) offers the most reliable results for detecting earnings management in emerging Eastern European post-communism economic environment. Additionally, based on broad analyses the results indicate that there is no superiority of the cross-sectional models vis-àvis their time-series counterparts. Both methodologies are consistent in detecting earnings management for Eastern European companies. Therefore, we verified the importance of the previous evaluation of the ability of each model for detecting earnings management before its application. It is because each economic environment has different peculiarities and circumstances, as observed in case of our developing European countries.
\end{abstract}

Keywords: Earnings Management; Discretionary Accruals; Detecting Earnings Management; Emerging Countries; Eastern European Countries. 
Cite This Article: Susana Callao, José I. Jarne, and David Wróblewski. (2017). "DETECTING EARNINGS MANAGEMENT INVESTIGATION ON DIFFERENT MODELS MEASURING EARNINGS MANAGEMENT FOR EMERGING EASTERN EUROPEAN COUNTRIES." International Journal of Research - Granthaalayah, 5(11), 222-259. https:// doi.org/10.29121/granthaalayah.v5.i11.2017.2351.

\section{Introduction}

Earnings management has received considerable attention in the accounting and financial literature. Nevertheless, the methodological aspect related to how efficiently measure earnings management was always a problem for the investigators, as over almost forty years of investigation there is no "perfect" model for measuring earnings management.

The literature pointed out the wide range of use of alternative models to measure earnings management. Such research requires models that estimate the discretionary component of reported earnings. Existing models range from simple models proposed by Healy (1985) and DeAngelo (1986), to more sophisticated models that attempt to separate total accruals into discretionary and nondiscretionary components, see for example, Jones (1991), Kasznik (1999), Kothari et al. (2005), among others.

However, there is no systematic evidence bearing on the relative performance of these alternative models at detecting earnings management. Usually, the authors centre on the measuring earnings management by the models most applicable and most popular in the literature on earnings management. In this way, drawing on the existing earnings management literature must be emphasized that the most popular five models are: the Jones (1991) model, the modified Jones model (Dechow, Sloan, and Sweeney, 1995), Teoh et al. (1998) model, Kasznik (1999) model and Kothari et al. (2005) model. Nevertheless, the body of literature on detecting earnings management confirms all these models have limitations, and the success of any earnings management study critically depends on the precise methodology used to measure it.

Therefore, this paper contributes to the literature on earnings management in several ways. First, this study represents the comprehensive attempt to examine remarkably ample investigation on existing models on earnings management. We evaluate and assess the ability of ten accruals models in detecting earnings management for emerging Eastern European countries. The purpose is to help and facilitate the selection the most appropriate model in detecting discretionary part of accruals. Each model relies on a different set of variables (for example, annual change in revenues, gross property, change in net receivables, operating expenses, cash flow from operations, among others), measuring the earnings management by different proxies. Each model requires at least one parameter to be estimated. The question emerges in relation to the selection of the set of variables, which are better to use, and more descriptively valid in evaluation of the discretionary part of accruals.

Secondly, little research has been conducted to date that evaluates the effectiveness of crosssectional version of each earnings management models vis-à-vis their time series counterparts. Only few studies try to compare the cross-sectional and time-series methods, see for example, Park and Ro (2004), Othman and Zeghal (2006), Ye (2007), Lo (2008). All these studies 
conclude that both methods (time-series, cross-sectional) do not always work well as indicated in the literature. So the comparative study is needed.

Third, this article also contributes to the earnings management literature by including numerous companies in the sample selection. At a broad spectrum of the complexity of the issue of the earnings management models' evaluations, authors within their attempts to evaluate the robustness of the models, they use relatively small samples; see for example, the study of Matis et al. (2010) who conduct study using a sample of 36 companies; Siregar and Utama (2008) using the sample of 144 firms; Bartov, Gul and Tsui (2000) sample of 166 firms; Mora and Sabater (2008) the sample of 281 listed firms; Kothari et al. (2005) sample of 500 firms. Our analysis comprises a total of 2,054 non-financial firms, which is very ample set of companies providing detailed and robustness results.

Furthermore, this investigation represents the first study evaluating models on earnings management based on the sample from the emerging Eastern European countries. Most of the papers published on the earnings management topics are based on the US, Asia or the Western Europe. Nevertheless, earnings management in Eastern Europe is still barely unexplored. We analyze the ability of the existing models on earnings management in post-communism economic environment. Under new and different circumstances the use of a common set of models can not guarantee the robustness of the results within this market. Besides, the market of growing Eastern European markets is becoming increasing developing and gaining importance. Therefore, this study may prepare the background for future line of investigation based on the samples from the Eastern European countries.

Finally, to be able to contrast our results for the market of the developing Eastern European countries, our study is based on the four independent samples. We consider four countries: Poland, the Czech Republic, Hungary, and Slovakia. Each country offers us one independent sample. Having four different samples allow us to compare the obtained results and contrast them within the different Eastern European countries. In effect, it helps to confirm the power and specification of different tests for measurement of earnings management.

Our results indicate that Jones (1991), Shivakumar (1996), Kasznik (1999) and Yoon and Miller (2002) models are the most reliable models in detecting and measuring earnings management in the Eastern European economic environment. Additionally, we observe that Yoon and Miller (2002) model, not so frequently used by the literature, present highly better results in terms of adjusted $\mathrm{R}^{2}$ comparing to other models. Therefore, our results confirm the importance of the previous evaluation of the ability of each model for detecting earnings management in the specific economic environment before its application. Each peculiarities and circumstances indeed may influence on the results in the verification and measurement of the earnings management.

Surprisingly, widely used by the literature modified Jones model (Dechow, Sloan and Sweeney, 1995) is not as reliable as can be expected for our samples of emerging countries.

The remainder of this article is structured as follows. First, we describe the nature of different metrics on earnings management and the literature review on existing papers measure the 
robustness of the models. Following section describes the list of existing models for detecting earnings management that are evaluated in this paper. Then we proceed to present sample selection and methodology: explaining the cross-sectional and time-series approaches. We also clarify the criteria for evaluating the earnings management models. Finally, the obtained results are drawn. To conclude, limitations and conclusions are presented in section 5.

\section{Literature Review}

Earnings management is a purposeful intervention in the external financial reporting, to reach earnings targets, by varying of the accounting practices. However, it is an action which takes place without violating accounting regulation, and taking benefits from a possibility to make a certain choices in policy and accounting system. This action can lead, but not necessary, to mislead stakeholders into believing certain financial information. Other definitions of earnings management can be found in Schipper (1989), Apellániz and Labrador (1995) and Healy and Wahlen (1999).

However, the success of any earnings management study critically depends on the precise methodology used to measure it. For example, McNichols (2000) distinguishes three methodologies commonly used in the literature: methodology based on aggregate accruals models, other based on specific accruals and those based on the distribution of earnings after management. First, there is a large literature that attempts to identify discretionary accruals based on the relation between total accruals and hypothesized explanatory factors. This literature began with Healy (1985) and DeAngelo (1986), who used total accruals and change in total accruals, respectively, as measures of management's discretion over earnings. Jones (1991) introduced a regression approach to control for nondiscretionary factors influencing accruals, specifying a linear relation between total accruals and change in sales and property, plant and equipment. Posterior studies are investigating earnings management models using the variations of the Jones model. These approaches are typically called aggregate accruals studies.

A second approach in the literature is to model a specific accrual, see for example, McNichols and Wilson (1988), Petroni (1992). These studies often focus on the industry settings in which a single accrual is sizable and requires substantial judgment. Based on these characteristics, as well as anecdotal evidence, the researchers have priors that management's discretion is likely to be reflected in a specific accrual or set of accruals. As with aggregate accruals studies, a key aspect of the research design task is modelling the behaviour of each specific accrual to identify its discretionary and nondiscretionary components. McNichols and Wilson (1988), for example, focus on residual provision for bad debt, estimated as the residual from a regression of the provision for bad debts on the allowance beginning balance, and current and future write-offs. Petroni (1992) claims loss reserve estimation error, measured as the five year development of loss reserves of property casualty insurers.

A third approach examines the statistical properties of earnings to be able to identify behaviour that influences earnings, as developed for example, by Burgstahler and Dichev (1997) and DeGeorge et al. (1999). These studies focus on the behaviour of earnings around a specified benchmark, such as zero or a prior quarter's earnings, to test whether the incidence of amounts above and below the benchmark are distributed smoothly, or reflect discontinuities due to the 
exercise of discretion. In details, a study of Burgstahler and Dichev (1997) shows that by focusing on the density of the distribution of earnings after management we can detect earnings management. Other study, Myers and Skinner (1999) test whether the number of consecutive earnings increase is greater than expected absent earnings management. They find that there are many more firms with long strings of consecutive increases in quarterly earnings than would be expected by chance and report some evidence that managers of these firms practice income smoothing to help achieve this result, among other studies.

Nevertheless, among the different methodologies used to measure earnings management, we may confirm that the approach based on accruals is mainly used by the authors.

Therefore, the literature pointed out the wide range of use of alternative models based on the aggregate accruals to measure earnings management. Existing models range from simple models in which discretionary accruals are measured as total accruals (see for example, Healy, 1985; DeAngelo, 1986), to more sophisticated models that attempt to separate total accruals into discretionary and nondiscretionary components (see for example, Jones, 1991; Kasznik, 1999, Kothari et al., 2005, among others). It is pointed out the importance of the precise isolation of managed accruals from the normal/unmanaged portion. Researchers on earnings management over many years of investigation make various attempts to make this kind of separation. However, there is no systematic evidence bearing on the relative performance of these alternative models at detecting earnings management.

In most of the studies, the authors centre on the measuring earnings management by the models most applicable and most popular in the literature on earnings management. The most popular five models are the Jones (1991) model, the modified Jones model (Dechow, Sloan, and Sweeney, 1995), Teoh et al. (1998) model, Kasznik (1999) model and Kothari et al. (2005) model. In total, these five models were applied in almost $60 \%$ of the studies on earnings management (see Figure 1).

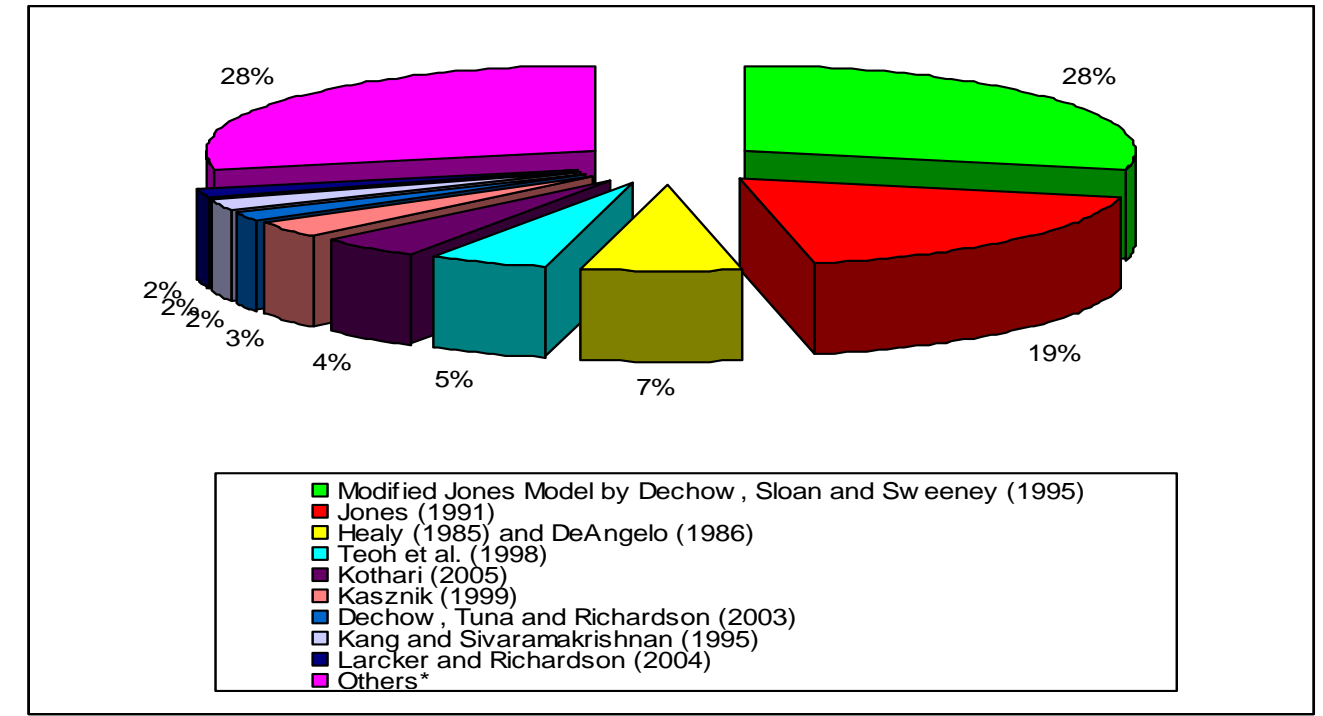

* The statistics are based on 195 analyzed papers, within the period of 1981-2011. The group "Others" include different ways of measuring discretionary accruals, such as: neural networks, questionnaires, the models of the ratio adjustment process, ratio of the absolute value of accruals to the absolute value of cash flow from operations, or there are descriptive works.

Figure 1: Percentage of studies using determined model of measuring earnings management 
In the literature, we may find small group of authors that have contrasted the obtained results obtained from different models. These studies recollect different models, determine the power of each of the model, and then identify the most appropriate way to measure earnings management. However, we can find only a few studies which take into the consideration the evaluation of different models, as follows.

The study by Dechow, Sloan and Sweeney (1995) is a first comprehensive paper which evaluates the power of earnings management models. They evaluate five models: Healy model (1985), DeAngelo model (1986), Jones model (1991), the industry model (Dechow and Sloan, 1991), modified Jones model (1995). Their results suggest that all the models considered appear to produce reasonable well specified tests for a random sample of event-years. However, the power of the tests is low for earnings management of economically plausible magnitudes, and when the models are applied for samples of firm-years experiencing extreme financial performance, all models lead to misspecified tests.

Bartov, Gul and Tsui (2000) evaluate empirically the ability of the cross-sectional version of two discretionary-accruals models, the cross-sectional Jones model (1991) and the cross-sectional modified Jones model (1995), to detect earnings management vis-à-vis their time series counterparts. They showed that the cross-sectional Jones model and the cross-sectional modified Jones model perform better than their time-series counterparts in detecting earnings management.

Yoon and Miller (2002), on the other side, compare two models: Jones model (1991) and Kang and Sivaramkrishinan (1995). Their results indicate that the Kang and Sivaramkrishinan model (1995) is a reliable model in estimating the nondiscretionary accruals for Korean firms.

Zhang (2002) evaluates the power of a comprehensive list of six earnings management detecting metrics: Healy model (1985), DeAngelo model (1986), modified Jones model (1995), crosssectional Jones model (1991), cross-sectional modified Jones model (1995). He obtained consistent results across different empirical tests. However, he did not draw out the conclusion which of the applied models is the best in detecting earnings management.

Kothari et al. (2005) examine the specification and power of tests based on performancematched discretionary accruals, and they make comparisons with tests using traditional discretionary accrual measures: Jones model (1991) and modified-Jones models (1995). The results suggested that Jones and modified-Jones models are severely misspecified in stratified random samples.

Ye (2007), on the other hand, does not compare the models directly. He measures earnings management using three models: Jones model (1991), Dechow, Sloan and Sweeney model (1995) and Kothari et al. model (2005), and contrasts the results. Therefore, the Kothari et al. model (2005) using simple pooled regression, demonstrates substantially better ability to capture the dynamics in accruals than commonly-used models such as the Jones model (1991) and the performance-adjusted Jones model (1995), whose parameters are estimated independently for each industry-year combination. The unexpected accruals generated by the Kothari et al. model (2005) are shown to have lower bias and greater power when testing earnings management, and 
demonstrate higher significance than the variables in original Jones model (1991) and the Dechow, Sloan and Sweeney model (1995).

Moreover, study of Mora and Sabater (2008) measures the political costs hypothesis of Continental European countries using a sample of Spanish companies, applying five models: Jones (1991) model and its extensions: Dechow et al. model, 1995; Kasznik model, 1999; Peasnell et al. model, 2000; and Kothari et al. model (2005); to analyze total and discretionary accruals around the time of labour negotiations. The results shows that Jones (1991), Kasznik (1999), and Kothari et al. (2005) models have lower level of their variables of long-term discretionary accruals version, and Jones (1991) and Dechow et al. (1995) models in their shortterm versions and for Peasnell et al., (2000) model, they observed the same results, that is, the presence of discretionary current accruals, statistically significant.

Siregar and Utama (2008) apply in their research four different models: Jones model (1991), Dechow, Sloan and Sweeney model (1995), Kasznik model (1999) and Dechow, Richardson and Tuna model (2003). They concluded that the ability of the Jones model and modified Jones model to accurately decompose accruals into non-discretionary and discretionary components is still questionable. Accordingly, there is a possibility of misclassification of non-discretionary and discretionary accruals. If some components of non-discretionary accruals are mistakenly classified as discretionary accruals, then this may explain the positive relation between discretionary accruals and some measures of future profitability.

Finally, in 2010, we find two more studies evaluating earnings management models. First one is a study of Dechow et al., who provide an approach for the detection of earnings management basing on the six models: Healy (1985) model, DeAngelo (1986) model, Jones (1991) model, Dechow, Sloan and Sweeney (1995) model, industry model (1996), Dechow and Dichev model (2002). Their results suggest that the power of typical accrual-based models can be almost doubled and misspecification in samples with extreme earnings performance is substantially mitigated.

The other study, Matis et al. (2010), makes an attempt of measuring the earnings management using an econometric model valid for the Romanian specificities by trying to establish the level of significance of three acknowledged econometric models: Jones (1991), Dechow et al. (1995) and Kasznik (1999) on Romanian economic environment. Their analyses lead to the conclusion that Jones model (1991) was found to be significant for Romanian economic environment.

Within the ample literature on earnings management we detect thirteen commonly used accruals models. Table 1 resumes models: equation and variables specifications.

Table 1: Models of measuring earnings management: Resume.

\begin{tabular}{|l|l|}
\hline Model & 1. The Healy Model (1985) \\
\hline \multirow{4}{*}{ Vormula } & $N D A_{t}=1 / n \sum_{t} \frac{T A_{i t}}{A_{i t-1}}$ \\
\hline & $\begin{array}{l}T A_{i t}-\text { Total Accruals in year } \mathrm{t} \\
A_{i t-1}-\text { Total Assets in year } \mathrm{t}-1 \\
\mathrm{n}-\text { number of years in the estimation period }\end{array}$ \\
\hline
\end{tabular}




\begin{tabular}{|c|c|}
\hline Model & 2. The DeAngelo Model (1986) \\
\hline Formula & $N D A_{i t}=\frac{T A_{i t-1}}{A_{i t-2}}$ \\
\hline Variables & $\begin{array}{l}T A_{i t-1}-\text { Total Accruals in year } \mathrm{t}-1 \\
A_{i t-2}-\text { Total Assets in year } \mathrm{t}-2\end{array}$ \\
\hline Model & 3. The Jones Model (1991) \\
\hline Formula & $\frac{T A_{i t}}{A_{i t-1}}=\alpha_{0} \frac{1}{A_{i t-1}}+\alpha_{1} \frac{\Delta R E V_{i t}}{A_{i t-1}}+\alpha_{2} \frac{P P E_{i t}}{A_{i t-1}}+\varepsilon_{i t}$ \\
\hline Variables & $\begin{array}{l}T A_{i t}-\text { Total Accruals in year } \mathrm{t} \\
A_{i t-1}-\text { Total Assets in year } \mathrm{t}-1 \\
\Delta R E V_{i t}-\text { Annual change in revenues in year } \mathrm{t} \\
P P E_{i t}-\text { Gross property, plant and equipment in year } \mathrm{t} \\
\varepsilon_{i t}-\text { The error term }\end{array}$ \\
\hline Model & 4. The Dechow, Sloan and Sweeney (called modified Jones Model, 1995) \\
\hline Formula & $T A_{i t}=\alpha_{0} \frac{1}{A_{i t-1}}+\alpha_{1} \frac{\Delta R E V_{i t}-\Delta R E C_{i t}}{A_{i t-1}}+\alpha_{2} \frac{P P E_{i t}}{A_{i t-1}}+\varepsilon_{i t}$ \\
\hline Variables & $\begin{array}{l}T A_{i t}-\text { Total Accruals in year } \mathrm{t} \\
A_{i t-1}-\text { Total Assets in year } \mathrm{t}-1 \\
\Delta R E V_{i t}-\text { Annual change in revenues in year } \mathrm{t} \\
\Delta R E C_{i t}-\text { Annual change in receivables accounts in year } \mathrm{t} \\
P P E_{i t}-\text { Gross property, plant and equipment in year } \mathrm{t} \\
\varepsilon_{i t}-\text { The error term }\end{array}$ \\
\hline Model & 5. The Kang and Sivaramakrishnan Model (1995) \\
\hline Formula & $\frac{A B_{i t}}{A_{i t-1}}=\alpha_{0} \frac{1}{A_{i t-1}}+\alpha_{1} \frac{\Delta R E V_{i t}}{A_{i t-1}}+\alpha_{2} \frac{E X P_{i t}}{A_{i t-1}}+\alpha_{3} \frac{P P E_{i t}}{A_{i t-1}}+\varepsilon_{i t}$ \\
\hline Variables & $\begin{array}{l}A B_{i t}-\text { Accrual balance in year } \mathrm{t}, \text { which is: } \\
A B_{i t}=A R_{i t}+I N V_{i t}+O C A_{i t}-C L_{i t}-D E P_{i t} \\
A R_{i t}-\text { Receivables } \\
I N V_{i t} \text { - Inventory } \\
O C A_{i t} \text { - Other current assets than cash, receivables, and inventory } \\
C L_{i t} \text { - Current liabilities excluding taxes and current maturities of long-term debt } \\
D E P_{i t} \text { - Depreciation and amortization } \\
A_{i t-1}-\text { Total Assets in year } \mathrm{t}-1 \\
\triangle R E V_{i t} \text { - Annual change in revenues in year } \mathrm{t} \\
E X P_{i t}-\text { Operating expenses in year } \mathrm{t} \\
P P E_{i t}-\text { Gross property, plant and equipment in year } \mathrm{t} \\
\varepsilon_{i t}-\text { The error term }\end{array}$ \\
\hline
\end{tabular}




\begin{tabular}{|c|c|}
\hline Model & 6. The Shivakumar Model (1996) \\
\hline Formula & $\frac{T A_{i t}}{A_{i t-1}}=\alpha_{0} \frac{1}{A_{i t-1}}+\alpha_{1} \frac{\Delta R E V_{i t}}{A_{i t-1}}+\alpha_{2} \frac{P P E_{i t}}{A_{i t-1}}+\alpha_{3} \frac{C F O_{i t}}{A_{i t-1}}+\varepsilon_{i t}$ \\
\hline Variables & $\begin{array}{l}T A_{i t}-\text { Total Accruals in year } \mathrm{t} \\
A_{i t-1}-\text { Total Assets in year } \mathrm{t}-1 \\
\triangle R E V_{i t}-\text { Annual change in revenues in year } \mathrm{t} \\
P P E_{i t}-\text { Gross property, plant and equipment in year } \mathrm{t} \\
C F O_{i t} \text { - Cash flow from operations in year } \mathrm{t} \\
\varepsilon_{i t}-\text { The error term }\end{array}$ \\
\hline Model & 7. Key Model (1997) \\
\hline Formula & $\frac{T A_{i t}}{A_{i t-1}}=\alpha_{0} \frac{1}{A_{i t-1}}+\alpha_{1} \frac{\Delta R E V_{i t}}{A_{i t-1}}+\alpha_{2} \frac{P P E_{i t}}{A_{i t-1}}+\alpha_{3} \frac{I A_{i t}}{A_{i t-1}}+\varepsilon_{i t}$ \\
\hline Variables & $\begin{array}{l}T A_{i t}-\text { Total Accruals in year } \mathrm{t} \\
A_{i t-1}-\text { Total Assets in year } \mathrm{t}-1 \\
\Delta R E V_{i t}-\text { Annual change in revenues in year } \mathrm{t} \\
P P E_{i t}-\text { Gross property, plant and equipment in year } \mathrm{t} \\
I A_{i t}-\text { Gross intangible assets in year } \mathrm{t} \\
\varepsilon_{i t}-\text { The error term }\end{array}$ \\
\hline Model & 8. The Teoh et al. Model (1998) \\
\hline Formula & $T A_{i t}=\alpha_{0} \frac{1}{A_{i t-1}}+\alpha_{1} \frac{\Delta S A L E_{i t}-\Delta R E C_{i t}}{A_{i t-1}}+\varepsilon_{i t}$ \\
\hline Variables & $\begin{array}{l}T A_{i t}-\text { Total Accruals in year } \mathrm{t} \\
A_{i t-1}-\text { Total Assets in year } \mathrm{t}-1 \\
\Delta S A L E_{i t}-\text { Change in sales in year } \mathrm{t} \\
\Delta R E C_{i t}-\text { Annual change in receivables in year } \mathrm{t} \\
\varepsilon_{i t}-\text { The error term }\end{array}$ \\
\hline Model & 9. The Kasznik Model (1999) \\
\hline Formula & $\frac{T A_{i t}}{A_{i t-1}}=\alpha_{0} \frac{1}{A_{i t-1}}+\alpha_{1} \frac{\Delta R E V_{i t}}{A_{i t-1}}+\alpha_{2} \frac{P P E_{i t}}{A_{i t-1}}+\alpha_{3} \frac{\Delta C F O_{i t}}{A_{i t-1}}+\varepsilon_{i t}$ \\
\hline Variables & $\begin{array}{l}T A_{i t}-\text { Total Accruals in year } \mathrm{t} \\
A_{i t-1}-\text { Total Assets in year } \mathrm{t}-1 \\
\triangle R E V_{i t}-\text { Annual change in revenues in year } \mathrm{t} \\
P P E_{i t}-\text { Gross property, plant and equipment in year } \mathrm{t} \\
\triangle C F O_{i t} \text { - Change in cash flow from operations in year } \mathrm{t} \\
\varepsilon_{i t}-\text { The error term }\end{array}$ \\
\hline Model & 10. The Yoon and Miller Model (2002) \\
\hline
\end{tabular}




\begin{tabular}{|c|c|}
\hline Formula & $\frac{T A_{i t}}{A_{i t-1}}=\alpha_{0} \frac{1}{A_{i t-1}}+\alpha_{1} \frac{\Delta R E V_{i t}-\Delta R E C_{i t}}{A_{i t-1}}+\alpha_{2} \frac{\Delta E X P_{i t}-\Delta P A Y_{i t}}{A_{i t-1}}+\alpha_{3} \frac{N C A S H_{i t-1} \times G P P E G R W}{A_{i t-1}}$ \\
\hline Variables & $\begin{array}{l}T A_{i t}-\text { Total Accruals in year } \mathrm{t} \\
A_{i t-1}-\text { Total Assets in year } \mathrm{t}-1 \\
\Delta R E V_{i t}-\text { Annual change in revenues in year } \mathrm{t} \\
\triangle R E C_{i t} \text { - Annual change in receivables accounts in year } \mathrm{t} \\
\triangle E X P_{i t} \text { - Change in operating expenses excluding non-cash expenses in year } \mathrm{t} \\
\triangle P A Y_{i t}-\text { Change in payables accounts in year } \mathrm{t} \\
N C A S H_{i t-1} \text { - Non-cash expenses such as depreciation in year } \mathrm{t}-1 \\
G P P E G R W_{i t} \text { - A rate of growth in gross property, plant and equipment in year } \mathrm{t} \\
\varepsilon_{i t}-\text { The error term }\end{array}$ \\
\hline Model & 11. The Dechow, Richardson, and Tuna Model (2003) \\
\hline Formula & $\frac{T A_{i t}}{A_{i t-1}}=\alpha_{0} \frac{1}{A_{i t-1}}+\alpha_{1} \frac{(1+k) \Delta R E V_{i t}-\Delta R E C_{i t}}{A_{i t-1}}+\alpha_{2} \frac{P P E_{i t}}{A_{i t-1}}+\alpha_{3} \frac{T A_{i t-1}}{A_{i t-2}}+\alpha_{4} \frac{\Delta S A L E_{i t}}{A_{i t}}$ \\
\hline Variables & $\begin{array}{l}T A_{i t}-\text { Total Accruals in year } \mathrm{t} \\
A_{i t-1}-\text { Total Assets in year } \mathrm{t}-1 \\
\mathrm{k}-\text { is a slope coefficient from regression } \triangle R E C_{i t} \text { on } \triangle R E V_{i t} \\
\Delta R E V_{i t} \text { - Annual change in revenues in year } \mathrm{t} \\
\Delta R E C_{i t} \text { - Annual change in receivables accounts in year } \mathrm{t} \\
P P E_{i t} \text { - Gross property, plant and equipment in year } \mathrm{t} \\
T A_{i t-1} \text { - Total Accruals in year } \mathrm{t}-1 \\
\Delta S A L E_{i t+1}-\text { Annual change in sales from current year }(\mathrm{t}) \text { to next year }(\mathrm{t}+1) \\
\left(S A L E_{t+1}-S A L E_{t}\right) / S A L E_{t} \\
\varepsilon_{i t}-\text { The error term }\end{array}$ \\
\hline Model & 12. The Larcker and Richardson Model (2004) \\
\hline Formula & $\frac{T A_{i t}}{A_{i t-1}}=\alpha_{0} \frac{1}{A_{i t-1}}+\alpha_{1} \frac{\Delta S A L E_{i t}-\Delta R E C_{i t}}{A_{i t-1}}+\alpha_{2} \frac{P P E_{i t}}{A_{i t-1}}+\alpha_{3} \frac{B M_{i t}}{A_{i t-1}}+\alpha_{4} \frac{C F O_{i t}}{A_{i t-1}}+\varepsilon_{i t}$ \\
\hline Variables & $\begin{array}{l}T A_{i t}-\text { Total Accruals in year } \mathrm{t} \\
A_{i t-1}-\text { Total Assets in year } \mathrm{t}-1 \\
\triangle S A L E_{i t}-\text { Change in sales in year } \mathrm{t} \\
\triangle R E C_{i t} \text { - Annual change in receivables accounts in year } \mathrm{t} \\
P P E_{i t}-\text { Gross property, plant and equipment in year } \mathrm{t} \\
B M_{i t}-\text { Book-to-market ratio in year } \mathrm{t} \\
C F O_{i t}-\text { Cash flow from operations in year } \mathrm{t} \\
\varepsilon_{i t}-\text { The error term }\end{array}$ \\
\hline
\end{tabular}




\begin{tabular}{|l|l|}
\hline Model & 13. The Kothari et al. Model (2005) \\
\hline \multirow{3}{*}{ Formula } & $\frac{T A_{i t}}{A_{i t-1}}=\alpha_{0} \frac{1}{A_{i t-1}}+\alpha_{1} \frac{\Delta S A L E_{i t}-\triangle R E C_{i t}}{A_{i t-1}}+\alpha_{2} \frac{P P E_{i t}}{A_{i t-1}}+\alpha_{3} \frac{R O A_{i t-1}}{A_{i t-1}}+\varepsilon_{i t}$ \\
\hline \multirow{5}{*}{ Variables } & $T A_{i t}-$ Total Accruals in year $\mathrm{t}$ \\
& $A_{i t-1}-$ Total Assets in year $\mathrm{t}-1$ \\
& $\Delta S A L E_{i t}-$ Change in sales in year $\mathrm{t}$ \\
& $\Delta R E C_{i t}-$ Annual change in receivables accounts in year $\mathrm{t}$ \\
& $P P E_{i t}-$ Gross property, plant and equipment in year $\mathrm{t}$ \\
& $R O A_{i t-1}-$ Return on assets in year $\mathrm{t}$ \\
& $\varepsilon_{i t}-$ The error term
\end{tabular}

Source: The author Based on the earnings management literature.

\section{Sample and Methodology}

\subsection{Sample}

The sample comprises a total of 2,054 non-financial firms from four Eastern European countries, specifically from the Czech Republic, Poland, Hungary and Slovakia, see Table 2. The analysis covers the period 2003 to 2008 and the sample comprises a total of 14,378 observations. Hungary is the country with the least observations (609) and the Czech Republic with the most observations $(7,168)$.

Table 2: Sample

\begin{tabular}{|l|l|l|}
\hline Country & Number of firms & Number of observations \\
\hline The Czech Republic & 1,024 & 7,168 \\
\hline Poland & 853 & 5,971 \\
\hline Hungary & 87 & 609 \\
\hline Slovakia & 90 & 630 \\
\hline & $\mathbf{2 , 0 5 4}$ & $\mathbf{1 4 , 3 7 8}$ \\
\hline
\end{tabular}

To generate this sample, we have used the AMADEUS data base, retaining only firms for which data were available with regard to the variables considered for all the years of the study (20032008) and for the prior period (2002) used to calculate changes in certain variables, as explained below. For each variable, we eliminated outliers, which are observations falling outside the range set by the mean value plus/minus three times the standard deviation ${ }^{1}$. In Annex 1 we present sample description.

\footnotetext{
${ }^{1}$ Most of the models require at least one parameter to be estimated. In this way, we have 10 different variables, such as, total assets, receivables accounts, payables accounts, operating revenues, cash flow, sales, return on assets (ROA), among others.
} 


\subsection{Methodology}

To detect earnings management we based on the accruals, specifically, on the discretionary part of the accruals. Accruals are defined as the part of revenues and expenses that do not imply collections and payments. Assuming that the latter cannot be manipulated, accruals (TA) would provide a way to manage earnings. However, not all accruals are equally capable of being manipulated, and we may therefore distinguish between non-discretionary accruals (NDA), which are more difficult for management to manage, and discretionary accruals, which are easier. Thus, $T A=N D A+D A$. The following expression (1) was used to calculate total accruals $\left(T A_{i t}\right):$

$T A_{i t}=\Delta \operatorname{Re}$ ceivables $_{i t}+\Delta$ Inventorie $_{i t}-\Delta$ Payables $_{i t}-D E P_{i t}$

Where $\Delta$ Receivables is the change in accounts receivable, $\Delta$ Inventories is the change in stocks, $\triangle$ Payables is the change in accounts payable and DEP is the depreciation and amortization expense $^{2}$. The subscripts $i$ and $t$ refer to the firm and the year respectively. Variations are calculated with respect to the prior year.

Since the discretionary and non-discretionary components of accruals are not directly observable, we use the models previously resumed. All models are scaled by lagged total assets. $A_{i t-1}$ is used as a deflator to avoid problems of heteroscedasticity. To secure the results and obtain consistent estimations, we also use the test of heteroscedasticity proposed by White (1980).

Within the thirteen models we had to abandon and discard the Healy model (1985) and the DeAngelo model (1986) from our analysis. These two models are the first attempts to measure the earnings management. However, they are based on misspecified assumption, that nondiscretionary accruals are constant from period to period. Both the Healy model and the DeAngelo model assume that nondiscretionary accruals are constant over time, and that changes can only be discretionary. Kaplan (1985) points out, that the level of nondiscretionary accruals should change in response to changes in economic circumstances, and the impact of the economic circumstances on nondiscretionary accruals will cause inflated standard error due to the omission of relevant (uncorrelated) variables.

In addition, both models measure earnings management in the "direct way", in the straight and instant manner show the scale of the manipulation ${ }^{3}$, which prevent us to evaluate the power of

\footnotetext{
${ }^{2}$ Total accruals can be also calculated as a difference between profit and operating cash.

${ }^{3}$ Healy (1985) model is trying the detect earnings management by estimating deviations from the average accruals. The mean total accruals from the estimation period then represent the measure of nondiscretionary accruals (NDA). Discretionary accruals are the result of deducting the nondiscretionary accruals from the total accruals. Earnings management is seen as any deviation from the average (Praag, 2001). In the same line of investigation, the DeAngelo (1986) model does not differ much from the Healy model. In the DeAngelo model the period of estimation for non discretionary accruals is focused on the prior year observation. The total accruals of the previous year are the measure of non discretionary accruals. This means that non-discretionary are equal to the total accruals of the last period (Bartov et al., 2000). The changes between this period and the previous period are seen as discretionary accruals.
} 
the models (regression models permit evaluation of the power of the models and the scale of the manipulation).

We also abandon the model of Larcker and Richardson (2004). Book-to-market variable and non-cash variable limit the sample significantly. Therefore, the missing data leads us to discard this model for the fact of the impossibility to obtain reliable sample data. In these circumstances, we centre analysis on ten accruals models on earnings management.

\subsection{Cross-Sectional Analysis Vs Time-Series Analysis}

Research designs in prior studies on earnings management can be summarized into two main categories: time series and cross-sectional analysis. Many studies on earnings management widely used either time-series data, studies such as: Jones (1991); Dechow, Sloan, and Sweeny (1995); Guay, Kothari, and Watts (1996); Kallunki and Martikainen (1999); McNichols (2000); Cormier and Martinez (2006); or cross-section data, studies such as: Subramanyam (1996); DeFond and Subramanyam (1998); Peasnell, Pope, and Young (2000); Bartov, Gul, and Tsui (2001), Larcker and Richardson (2003); Park and Shin (2004); Roychowdhury (2006); Jaggi and Leung (2007), Siregar and Utama (2008); among others. However, there is no consensus about which of the analysis offers better results. Both approaches have limitations.

The time-series methods and the cross-sectional methods provide conceptually different estimates of abnormal accruals due to differences in their approaches for estimating expected accruals. To estimate model parameters, time-series methods use data from an estimation period during which no systematic earnings management is expected to occur. Cross-sectional methods make no assumptions regarding systematic earnings management in the estimation sample but implicitly assume that the model parameters are the same across all firms in an estimation sample (Jeter and Shivakumar, 1999).

The time-series approach assumes temporal stationary of parameter estimates, whereas the crosssectional approach assumes homogeneity across firms in the same industry (Larker and Richardson, 2004). Moreover, the temporal model requires the sample to have at least ten observations for each firm. It means, the time series approach suffers from the typically short time series data available, and ignores time variation in accruals intensities (Ye, 2007). For studies using annual data, this requirement implies that the sample firms must survive for at least eleven years. Since such firms are more likely to be large, mature firms with greater reputational capital to lose if earnings management is uncovered, this methodology introduces a selection bias.

On the other hand, the cross-sectional method is less likely to detect any abnormal accruals if such accruals are correlated across several firms in the same industry. It is because the discretionary accruals are more firm specific than industry-specific (Ebrahim, 2001). Jeter and Shivakumar (1999) state even more, that if firms' smooth reported earnings, the cross-sectional methods are unlikely to capture the negative abnormal accruals. Only those firms whose accruals are negative relative to the industry benchmark will be identified as earnings managers. This is a significant limitation of the cross-sectional approach. 
The literature indicates that cross-sectional methods are more widely used in earnings management studies. See for example, Subramanyam (1996) who states that cross-sectional methods have been generally well received in the literature and have been used in a number of papers. Dechow, Sloan and Sweeney (1995) also point out that the cross-sectional version has several advantages, such as: (a) it generates a larger sample size to facilitate hypothesis testing; (b) the number of observations per model is greater for the cross-sectional method, which enhances the efficiency and precision of the estimates; (c) the time-series method suffers potential survivorship bias as it generally requires a minimum of 10 years of observations to achieve a reasonable level of estimation efficiency (Dechow et al., 1995). Koh (2003) adds the fourth advantage (d) given the lengthy time period required by the time-series method, it is possible for the model to be misspecified due to non-stationary. Bartow et al. (2000) again insist that the cross-sectional version performs better than the time-series counterpart.

Table 3 indicates clearly the pre-eminence of the application the cross-sectional methods to the time-series methods in the earnings management methodology. Cross-sectional methods evidently dominate the earnings management literature. More than two thirds of the earnings management studies (68\%) apply the cross-sectional methodology. Only 16 of the 185 studies, which are 9\%, use the time-series methodology.

However, little research has been conducted to date that evaluates the effectiveness of these methods at detecting earnings management. Only four studies try to compare the cross-sectional and time-series methods.

Lo (2008) makes a theoretical research on the cross-sectional and time-series approaches. He points out, that generally models can be summarized into three categories: time series, crosssectional, and cross-country, where the cross-country approach is a variation of the crosssectional approach.

Table 3: Cross-sectional vs. time-series analysis

\begin{tabular}{|c|c|c|}
\hline & Number of studies & Percentage \\
\hline Cross-sectional & 126 & $68.11 \%$ \\
\hline Time-series & 16 & $8.65 \%$ \\
\hline Both: Cross-sectional and Time-series & 6 & $3.24 \%$ \\
\hline \multirow[t]{2}{*}{ Other methodology } & $37 * *$ & $20.00 \%$ \\
\hline & $185 *$ & $100.00 \%$ \\
\hline
\end{tabular}

* We have investigated total of 195 papers on earnings management, however, there are 10 theoretical papers without using methodology.

**The percentage of the other methodology indicates the application of the different methodology (not using time-series or crosssectional) such as: using logistic regressions (Kerstein and Rai, 2007); or using an asymmetric information model (Chaney and Lewis, 1995); or for example, calculated using a model that incorporate any changes in the discretionary accruals without employing the accounting methods directly (Darrough, Pourjalali and Saudagaran, 1998), among others.

Othman and Zeghal (2006), also in a theoretical study, show the advantages and disadvantages of each of the methods. Ye (2007) as well propose accruals model displays the advantages of both the cross-sectional and the time-series Jones models. Park and Ro (2004) try to evaluate based on the sample firms, and they conclude that these methods (time-series, cross-sectional) do not always work well as indicated in the literature. 


\subsection{Criteria To Evaluate Earnings Management Models}

To determine the reliability of each of the model, based on the earnings management literature, we use four measures: explanatory power (adjusted $R^{2}$ ), predicted sign of the variables, the standard errors of the variables and the level of the significance of the variables.

Explanatory power (adjusted $\boldsymbol{R}^{2}$ ) has been widely used by the authors as a measure of strength of the models on earnings management. We may find it in numerous studies, such as, Key (1997), Peasnell, Pope and Young (1999), McNichols (2000), Yoon and Miller (2002), Burgstahler, Hail and Leuz (2006), Ye (2007), Siregar and Utama (2008).

Second measure used by the earnings management literature, is predicted sign of the variables, see for example studies of: Peasnell, Pope and Young (1999), McNichols (2000), Bartov, Gul and Tsui (2000), Jeanjean (2000), Seok Park and Park (2004), Kothari et al. (2005), Ye (2007), Dechow et. al. (2010), Matis et al. (2010). Predicted sign of the variables indicates if the expectation of the relation with other variables is met. If corrected sign is received, the model explains in better way the phenomenon of earnings management. If the variable obtains different sign than expected, variable should be excluded from the model.

Third test is standard errors of the variables. Many authors also use the standard error to determine the effectiveness the model to detect earnings management, see for example, Dechow, Sloan and Sweeney (1995), Konings, Labro and Roodhooft (1998), McNichols (2000), Bartov, Gul and Tsui (2000), Jeanjean (2000), Seok Park and Park (2004), Kothari et al. (2005), Siregar and Utama (2008), Mora and Sabater (2008). Analysis of the standard deviation is used to describe the variability in samples. As state the literature, see for example Blalock (1979), Snedecor and Cochran (1980), Weisberg (1985), Neter (1993), among others, standard deviation is used to show how much variation or dispersion exists from the average (mean).

Finally, the last test of the "goodness" of the earnings management models is a significance test. Statistical significance of the variables informs about the degree to which the results are true, in the sense of being representative of the population. It confirms about the goodness of fit of the model (Blalock, 1979; Snedecor and Cochran, 1980; Weisberg, 1985, Neter, 1993). High significance means better model. No significance of the variable means that the variable should be excluded from the model. Wide range of studies use standard deviation to evaluate the power of earnings management models, see for example, studies of Dechow, Sloan and Sweeney (1995), Konings, Labro and Roodhooft (1998), Rangan (1998), McNichols (2000), Bartov, Gul and Tsui (2000), Yoon and Miller (2002), Zhang (2002), Seok Park and Park (2004), Siregar and Utama (2008), Mora and Sabater (2008), Dechow et al. (2010), Matis et al. (2010), among others.

\section{Results}

\subsection{Cross-Sectional Approach}

Table 4 reports the summary of the explanatory power of the models (adjusted $\mathrm{R}^{2}$ ) by country. We may observe that adjusted $\mathrm{R}^{2}$ presents the highest values for Yoon and Miller model (2002), 
followed by Shivakumar (1996) model and Kasznik model (1999). Yoon and Miller (2002) model shows very high values rounding $37.54 \%$ for all four countries. Two following models present adjusted $\mathrm{R}^{2}$ mean close to $12 \%$. Finally, Jones (1991), Kang and Sivaranakrishnan (1995), Key (1997) and Dechow, Richardson and Tuna (2003) show results rounding 9\%.

On the other hand, adjusted $\mathrm{R}^{2}$ for Teoh et al. model (1998) is very low for all our four samples, even decreases significantly to reach negative values. Greene (2002) in his econometric study pointed out that the adjusted $\mathrm{R}^{2}$ may decline even to negative values when a variable is added to the set of independent variables. It is considered an admittedly extreme case, suppose of misspecified model.

Table 4: Mean values of Adjusted $\mathrm{R}^{2}$ by models and across the countries' samples

\begin{tabular}{|l|l|l|l|l|l|}
\hline Measurement model & \multicolumn{2}{|l|}{ Sample countries } & \\
\hline Mean value of $\mathbf{R}^{\mathbf{2}}$ & The Czech Republic & Poland & Hungary & Slovakia & Mean \\
\hline Jones (1991) & 0.0947 & 0.0666 & 0.0890 & 0.0996 & $\mathbf{0 . 0 8 7 5}$ \\
\hline Modified Jones (1995) & 0.0452 & 0.0617 & 0.0511 & 0.0806 & $\mathbf{0 . 0 5 9 7}$ \\
\hline Kang and Sivaranakrishnan (1995) & 0.0973 & 0.0796 & 0.0821 & 0.0900 & $\mathbf{0 . 0 8 7 2}$ \\
\hline Shivakumar (1996) & 0.0995 & 0.1449 & 0.1200 & 0.0953 & $\mathbf{0 . 1 1 4 9}$ \\
\hline Key (1997) & 0.0957 & 0.0705 & 0.0796 & 0.0906 & $\mathbf{0 . 0 8 4 1}$ \\
\hline Teoh, Welch and Wong (1998) & 0.0120 & 0.0287 & 0.0192 & -0.0060 & $\mathbf{0 . 0 1 3 5}$ \\
\hline Kasznik (1999) & 0.0953 & 0.1423 & 0.1177 & 0.1106 & $\mathbf{0 . 1 1 6 5}$ \\
\hline Yoon and Miller (2002) & 0.3490 & 0.3733 & 0.3500 & 0.4292 & $\mathbf{0 . 3 7 5 4}$ \\
\hline Dechow, Richardson and Tuna (2003) & 0.0668 & 0.0848 & 0.0800 & 0.1079 & $\mathbf{0 . 0 8 4 9}$ \\
\hline Kothari, Leone and Wasley (2005) & 0.0405 & 0.0661 & 0.0599 & 0.0910 & $\mathbf{0 . 0 6 4 4}$ \\
\hline
\end{tabular}

To contrast the results, the Table 5 presents the resume of the results on adjusted $\mathrm{R}^{2}$ for the four countries by year. We may identify again that Yoon and Miller (2002), Shivakumar (1996) and Kasznik models (1999) report better results then other models. These three models are the unique models reaching the results of adjusting $\mathrm{R}^{2}$ above the $20 \%$. Nevertheless, Yoon and Miller (2002) model again presents results rounding $37 \%$ of adjusted $\mathrm{R}^{2}$, which is highly above the others.

Additionally, Jones (1991) and Kand and Sivaranakrishnan (1995) also report reliable results over years, presenting in two first years (2003 and 2004) the results of adjusted $\mathrm{R}^{2}$ rounding $17 \%$, then the values decrease. The lowest values of adjusted $\mathrm{R}^{2}$ present Teoh et al. model (1998), Dechow, Richardson and Tuna model (2003) and Kothari et al. model (2005) hardly two times they go over the $10 \%$.

Table 5: Mean values of adjusted $\mathrm{R}^{2}$ for a total of four samples along the years

\begin{tabular}{|l|l|l|l|l|l|l|l|}
\hline Measurement model & \multicolumn{4}{l|}{ Years } & \multicolumn{2}{l|}{} \\
\hline Mean value of R $\mathbf{R}^{\mathbf{2}}$ & 2003 & 2004 & 2005 & 2006 & 2007 & 2008 & Mean \\
\hline Jones (1991) & 0.1175 & 0.1720 & 0.0355 & 0.0811 & 0.0552 & 0.0636 & $\mathbf{0 . 0 8 7 5}$ \\
\hline Modified Jones (1995) & 0.0470 & 0.1405 & 0.0264 & 0.0772 & 0.0292 & 0.0376 & $\mathbf{0 . 0 5 9 7}$ \\
\hline Kang and Sivaranakrishnan (1995) & 0.1124 & 0.1777 & 0.0344 & 0.0790 & 0.0600 & 0.0600 & $\mathbf{0 . 0 8 7 2}$ \\
\hline Shivakumar (1996) & 0.2298 & 0.1816 & 0.0569 & 0.0965 & 0.0594 & 0.0653 & $\mathbf{0 . 1 1 4 9}$ \\
\hline
\end{tabular}




\begin{tabular}{|l|l|l|l|l|l|l|l|} 
Key (1997) & 0.1126 & 0.1690 & 0.0305 & 0.0778 & 0.0507 & 0.0639 & $\mathbf{0 . 0 8 4 1}$ \\
\hline Teoh, Welch and Wong (1998) & 0.0135 & 0.0240 & 0.0230 & 0.0066 & -0.0012 & 0.0151 & $\mathbf{0 . 0 1 3 5}$ \\
\hline Kasznik (1999) & 0.2090 & 0.1974 & 0.0521 & 0.1093 & 0.0628 & 0.0682 & $\mathbf{0 . 1 1 6 5}$ \\
\hline Yoon and Miller (2002) & 0.4764 & 0.3812 & 0.4365 & 0.2943 & 0.3438 & 0.3200 & $\mathbf{0 . 3 7 5 4}$ \\
\hline Dechow, Richardson and Tuna (2003) & & 0.1606 & 0.0538 & 0.0868 & 0.0384 & & $\mathbf{0 . 0 8 4 9}$ \\
\hline Kothari, Leone and Wasley (2005) & 0.0502 & 0.1357 & 0.0516 & 0.0844 & 0.0317 & 0.0327 & $\mathbf{0 . 0 6 4 4}$ \\
\hline
\end{tabular}

Table 6 presents the details on the predicted sign of the coefficients. The percentage for each model is calculated as a number of times the variable gets the expected sign to the total number of observations. We have six year period of observation; therefore, we calculate the percentage of the expected sign as a relation (division) between the number of times the variable obtains expected sign to the total of years (divided into six) (total regressions).

The most consistent results present Jones model (1991). It has almost 100\% proportion of coefficients that fulfil the predicted sign (only for Hungary sample we observe 83.33\%). Modified Jones model (1995) and Key model (1997) seem to be also very reliable models in estimating the non-discretionary accruals related to predicted sign. Nearly all variables for all four samples indicate high percentage of expected sign, closely to $100 \%$. Only Poland and Slovakia for the first variable of Modified Jones model (1995) ( $\triangle \mathrm{REV}-\triangle \mathrm{REC}$ ) show $50.00 \%$ of predicted sign; and third variable (IA) present as well the $50 \%$ of expected sign for Hungary and Slovakia samples.

Furthermore, variables for the Yoon and Miller model (2002) show consistent signs. Changes in the cash revenues variable, $\triangle \mathrm{REV}-\triangle \mathrm{REC}$ have negative relationships with TA (total accruals variable). We obtain this result for all regressions. Changes in cash expenses, $\triangle$ EXP- $\triangle \mathrm{PAY}$ has positive relationships with TA (total accruals), and they show $100 \%$ of expected sign. Finally, non-cash expenses capture the non-discretionary nature of non-current accruals. They show negative relationships with TA. Approximately two thirds of them have the expected sign of the regression.

Other models in most of the cases present the right and adequate results for the relationship of the independent variables with the dependent variables. However, in some cases, the regressions do not show such clearly expected relationship, see for example Shivakumar model (1996) where the third variable of cash flow, the expected relationship in most of the cases is not fulfilled. In the same way, the variable of change in cash flow should have negative relationship (Kasznik model, 1999); however, our regressions show poor results, $0.00 \%, 16.67 \%, 16.67 \%$ and $33.33 \%$, respectively for the Czech Republic, Poland, Hungary and Slovakia regressions.

Table 7 provides summary results on standard deviation and mean values on the variables by the models and by the different samples. The results are divided within the panels which correspond to each model. Note that the mean standard errors are similar for all models, showing relatively high level, ranging from $10 \%$ to even $200 \%$. For example, Kasznik model (1999) shows high errors, ranging between $13 \%$ even to $200 \%$ of the mean of the variable (see Hungary sample standard deviation for $\triangle \mathrm{REV}$ is 0.0261 , and mean 0.0117 ). 
Table 6: Evaluation of earnings management measurement models: predicted sign

\begin{tabular}{|c|c|c|c|c|c|}
\hline \multirow[t]{2}{*}{$\begin{array}{l}\text { Measurement model: } \\
\text { variables and predicted sign }\end{array}$} & \multicolumn{5}{|c|}{$\begin{array}{l}\text { \% of the predicted sign. It is calculated as a number of } \\
\text { times the variable gets the expected sign to the total } \\
\text { number of observations }\end{array}$} \\
\hline & $\begin{array}{l}\text { The Czech } \\
\text { Republic }\end{array}$ & Poland & Hungary & Slovakia & Total \\
\hline \multicolumn{6}{|l|}{ Jones (1991) } \\
\hline$\triangle \mathrm{REV}(+)$ & $100.00 \%$ & $100.00 \%$ & $83.33 \%$ & $100.00 \%$ & $95.83 \%$ \\
\hline PPE (-) & $100.00 \%$ & $100.00 \%$ & $100.00 \%$ & $100.00 \%$ & $100.00 \%$ \\
\hline \multicolumn{6}{|l|}{ Modified Jones (1995) } \\
\hline$\triangle \mathrm{REV}-\Delta \mathrm{REC}(+)$ & $83.33 \%$ & $50.00 \%$ & $66.67 \%$ & $50.00 \%$ & $62.50 \%$ \\
\hline PPE (-) & $100.00 \%$ & $100.00 \%$ & $100.00 \%$ & $100.00 \%$ & $100.00 \%$ \\
\hline \multicolumn{6}{|l|}{ Kang and Sivaranakrishnan (1995) } \\
\hline$\triangle \mathrm{REV}(+)$ & $100.00 \%$ & $100.00 \%$ & $83.33 \%$ & $100.00 \%$ & $95.83 \%$ \\
\hline $\operatorname{EXP}(+)$ & $33.33 \%$ & $16.67 \%$ & $66.67 \%$ & $50.00 \%$ & $50.00 \%$ \\
\hline PPE (-) & $100.00 \%$ & $100.00 \%$ & $83.33 \%$ & $100.00 \%$ & $95.83 \%$ \\
\hline \multicolumn{6}{|l|}{ Shivakumar (1996) } \\
\hline$\triangle \mathrm{REV}(+)$ & $100.00 \%$ & $100.00 \%$ & $83.33 \%$ & $100.00 \%$ & $95.83 \%$ \\
\hline PPE (-) & $100.00 \%$ & $100.00 \%$ & $100.00 \%$ & $100.00 \%$ & $100.00 \%$ \\
\hline CFO (-) & $83.33 \%$ & $16.67 \%$ & $16.67 \%$ & $50.00 \%$ & $41.67 \%$ \\
\hline \multicolumn{6}{|l|}{ Key (1997) } \\
\hline$\triangle \mathrm{REV}(+)$ & $100.00 \%$ & $100.00 \%$ & $83.33 \%$ & $100.00 \%$ & $95.83 \%$ \\
\hline PPE (-) & $100.00 \%$ & $100.00 \%$ & $100.00 \%$ & $100.00 \%$ & $100.00 \%$ \\
\hline IA (-) & $100.00 \%$ & $83.33 \%$ & $50.00 \%$ & $50.00 \%$ & $70.83 \%$ \\
\hline \multicolumn{6}{|l|}{ Teoh, Welch and Wong (1998) } \\
\hline$\Delta$ SALE- $\triangle$ REC $(+)$ & $83.33 \%$ & $83.33 \%$ & $66.67 \%$ & $33.33 \%$ & $66.67 \%$ \\
\hline \multicolumn{6}{|l|}{ Kasznik (1999) } \\
\hline$\triangle \mathrm{REV}(+)$ & $100.00 \%$ & $50.00 \%$ & $83.33 \%$ & $83.33 \%$ & $79.17 \%$ \\
\hline PPE (-) & $100.00 \%$ & $100.00 \%$ & $100.00 \%$ & $100.00 \%$ & $100.00 \%$ \\
\hline$\triangle \mathrm{CFO}(-)$ & $0.00 \%$ & $16.67 \%$ & $16.67 \%$ & $33.33 \%$ & $16.67 \%$ \\
\hline \multicolumn{6}{|l|}{ Yoon and Miller (2002) } \\
\hline$\triangle \mathrm{REV}-\triangle \mathrm{REC}(-)$ & $100.00 \%$ & $100.00 \%$ & $100.00 \%$ & $100.00 \%$ & $100.00 \%$ \\
\hline$\Delta \mathrm{EXP}-\Delta \mathrm{PAY}(+)$ & $100.00 \%$ & $100.00 \%$ & $100.00 \%$ & $100.00 \%$ & $100.00 \%$ \\
\hline NCASH-1xGPPEGRW (-) & $16.67 \%$ & $83.33 \%$ & $83.33 \%$ & $66.67 \%$ & $62.50 \%$ \\
\hline \multicolumn{6}{|l|}{$\begin{array}{l}\text { Dechow, Richardson and Tuna } \\
(2003)\end{array}$} \\
\hline$(1+\mathrm{k}) \Delta \mathrm{REV}-\Delta \mathrm{REC}(+)$ & $100.00 \%$ & $25.00 \%$ & $75.00 \%$ & $75.00 \%$ & $68.75 \%$ \\
\hline PPE (-) & $100.00 \%$ & $100.00 \%$ & $100.00 \%$ & $100.00 \%$ & $100.00 \%$ \\
\hline TA-1 (+) & $25.00 \%$ & $25.00 \%$ & $25.00 \%$ & $50.00 \%$ & $31.25 \%$ \\
\hline$\Delta \mathrm{SALE}+1(+)$ & $75.00 \%$ & $50.00 \%$ & $100.00 \%$ & $75.00 \%$ & $75.00 \%$ \\
\hline \multicolumn{6}{|l|}{ Kothari, Leone and Wasley (2005) } \\
\hline$\triangle \mathrm{SALE}-\triangle \mathrm{REC}(+)$ & $83.33 \%$ & $50.00 \%$ & $66.67 \%$ & $33.33 \%$ & $58.33 \%$ \\
\hline PPE (-) & $100.00 \%$ & $100.00 \%$ & $100.00 \%$ & $100.00 \%$ & $100.00 \%$ \\
\hline ROA-1 (-) & $66.67 \%$ & $83.33 \%$ & $83.33 \%$ & $66.67 \%$ & $75.00 \%$ \\
\hline
\end{tabular}


where: $T A_{i t-1}$ - Total Accruals in year t-1; $\triangle R E V_{i t}$ - Annual change in revenues in year t; $\triangle R E C_{i t}$ - Annual change in receivables accounts in year $\mathrm{t} ; P P E_{i t}$ - Gross property, plant and equipment in year $\mathrm{t}$; $E X P_{i t}$ - Operating expenses in year t; $\triangle E X P_{i t}$ - Change in operating expenses excluding non-cash expenses in year t; $C F O_{i t}$ - Cash flow from operations in year $\mathrm{t} ; \triangle C F O_{i t}$ - Change in cash flow from operations in year $\mathrm{t}$; $I A_{i t}$ - Gross intangible assets in year $\mathrm{t}$; $\triangle S A L E_{i t}$ - Change in sales in year $\mathrm{t} ; R O A_{i t-1}$ - Return on assets in year $\mathrm{t}$; $\mathrm{k}$ - is a slope coefficient from regression $\triangle R E C_{i t}$ on $\triangle R E V_{i t}$.

Among all models, it seems that Jones model (1991) and modified Jones model (1995) show slightly better results showing lowest values of the standard deviation within the presented models. Modified Jones model (1995) the standard errors still remain high as in the previous model, rounding from $10 \%$ of the variable but do not exceed $60 \%$. Jones model (1991) the error is rounding between $10 \%$ to $50 \%$ for Slovakia firms in 2008 for the variable: fixed assets.

Table 7: Results on mean values and standard deviation by models by the samples

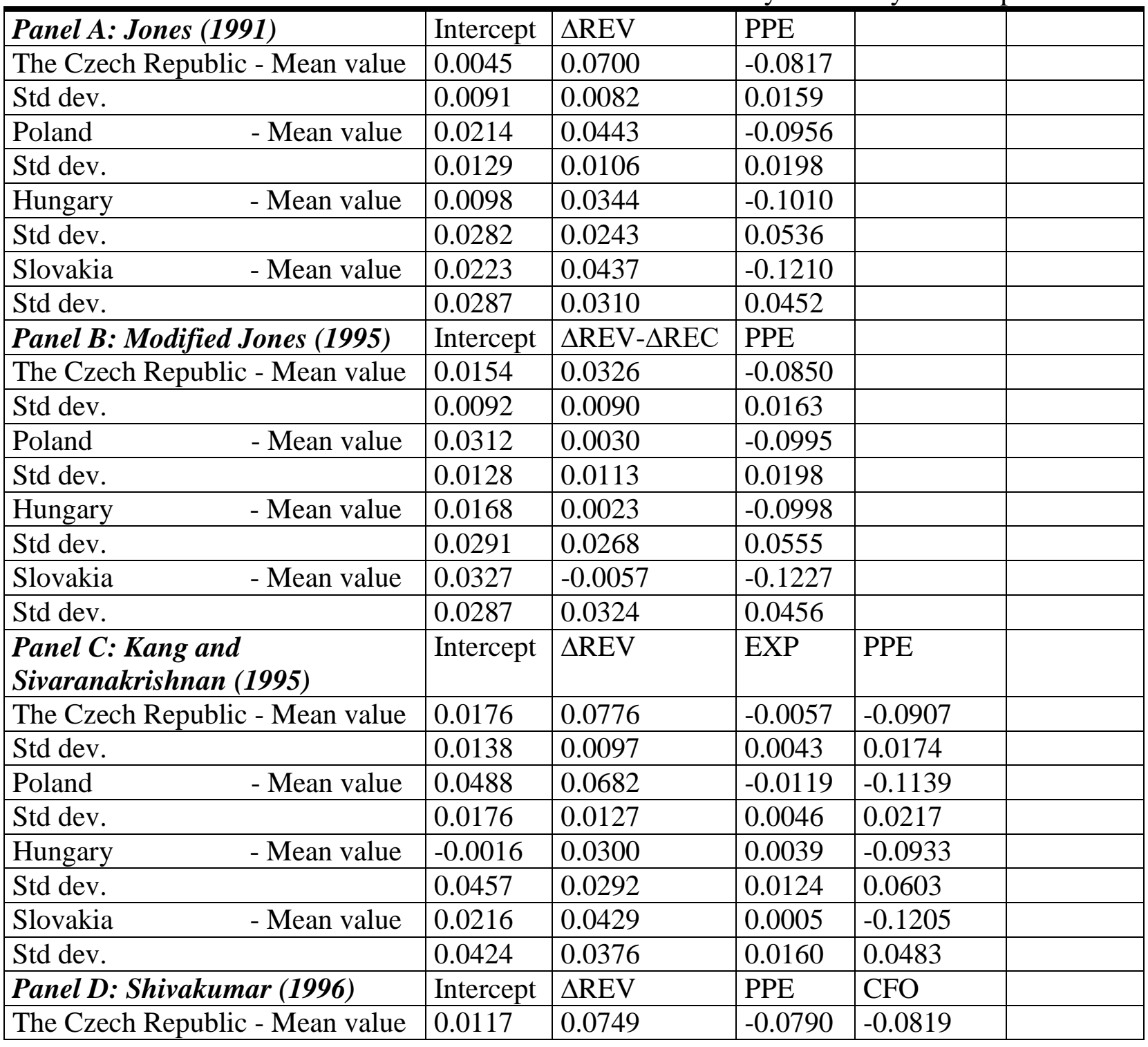




\begin{tabular}{|c|c|c|c|c|}
\hline Std dev. & 0.0097 & 0.0086 & 0.0159 & 0.0405 \\
\hline - Mean value & 0.0114 & 0.0362 & -0.0833 & 0.0175 \\
\hline Std dev. & 0.0129 & 0.0104 & 0.0184 & 0.0391 \\
\hline - Mean value & -0.0114 & 0.0233 & -0.1147 & 0.2196 \\
\hline Std dev. & 0.0299 & 0.0243 & 0.0528 & 0.1213 \\
\hline - Mean value & 0.0246 & 0.0439 & -0.1217 & -0.0192 \\
\hline Std dev. & 0.0313 & 0.0318 & 0.0459 & 0.1409 \\
\hline Panel E: Key (1997) & Intercept & $\triangle \mathrm{REV}$ & $\mathrm{PPE}$ & IA \\
\hline The Czech Republic - Mean value & 0.0063 & 0.0702 & -0.0813 & -0.1721 \\
\hline Std dev. & 0.0092 & 0.0082 & 0.0159 & 0.1285 \\
\hline - Mean value & 0.0225 & 0.0465 & -0.0947 & -0.1337 \\
\hline Std dev. & 0.0130 & 0.0107 & 0.0198 & 0.1184 \\
\hline - Mean value & 0.0091 & 0.0344 & -0.0993 & 0.0011 \\
\hline Std dev. & 0.0284 & 0.0245 & 0.0556 & 0.1888 \\
\hline - Mean value & 0.0223 & 0.0433 & -0.1209 & 0.0037 \\
\hline Std dev. & 0.0288 & 0.0312 & 0.0457 & 0.2558 \\
\hline Panel F: Teoh et al. (1998) & Intercept & $\begin{array}{l}\triangle \text { SALE- } \\
\triangle \text { REC }\end{array}$ & & \\
\hline The Czech Republic - Mean value & -0.0230 & 0.0200 & & \\
\hline Std dev. & 0.0051 & 0.0096 & & \\
\hline - Mean value & -0.0278 & 0.0049 & & \\
\hline Std dev. & 0.0064 & 0.0114 & & \\
\hline - Mean value & -0.0271 & 0.0073 & & \\
\hline Std dev. & 0.0172 & 0.0276 & & \\
\hline - Mean value & -0.0338 & -0.0147 & & \\
\hline Std dev. & 0.0142 & 0.0360 & & \\
\hline Panel G: Kasznik (1999) & Intercept & $\triangle \mathrm{REV}$ & PPE & $\triangle \mathrm{CFO}$ \\
\hline The Czech Republic - Mean value & 0.0048 & 0.0666 & -0.0826 & 0.0574 \\
\hline Std dev. & 0.0091 & 0.0089 & 0.0159 & 0.0544 \\
\hline - Mean value & 0.0170 & 0.0267 & -0.0842 & 0.1353 \\
\hline Std dev. & 0.0122 & 0.0108 & 0.0187 & 0.0504 \\
\hline - Mean value & 0.0155 & 0.0117 & -0.1122 & 0.3129 \\
\hline Std dev. & 0.0278 & 0.0261 & 0.0527 & 0.1783 \\
\hline - Mean value & 0.0231 & 0.0410 & -0.1269 & 0.1807 \\
\hline Std dev. & 0.0289 & 0.0320 & 0.0458 & 0.1904 \\
\hline Panel H: Yoon and Miller (2002) & Intercept & $\Delta \mathrm{REV}-\Delta \mathrm{REC}$ & $\begin{array}{l}\Delta \mathrm{EXP}- \\
\Delta \mathrm{PAY}\end{array}$ & $\begin{array}{l}\text { NCASH- } \\
\text { 1xGPPEG } \\
\text { RW } \\
\end{array}$ \\
\hline The Czech Republic - Mean value & -0.0356 & -0.5163 & 0.6076 & 0.1970 \\
\hline Std dev. & 0.0042 & 0.0256 & 0.0271 & 0.1292 \\
\hline - Mean value & -0.0354 & -0.5746 & 0.6530 & -0.4207 \\
\hline Std dev. & 0.0054 & 0.0293 & 0.0305 & 0.2044 \\
\hline - Mean value & -0.0360 & -0.5522 & 0.5898 & -0.3526 \\
\hline Std dev. & 0.0139 & 0.0884 & 0.0920 & 0.6357 \\
\hline - Mean value & -0.0465 & -0.5000 & 0.5800 & -0.6218 \\
\hline
\end{tabular}




\begin{tabular}{|c|c|c|c|c|c|}
\hline Std dev. & $\mid 0.0110$ & 0.0736 & 0.0790 & 0.5110 & \\
\hline $\begin{array}{l}\text { Panel I: Dechow, Richardson and } \\
\text { Tuna (2003) }\end{array}$ & Intercept & $\begin{array}{l}(1+\mathrm{k}) \Delta \mathrm{REV}- \\
\Delta \mathrm{REC}\end{array}$ & PPE & TA-1 & $\Delta \mathrm{SALE}+1$ \\
\hline The Czech Republic - Mean value & 0.0119 & 0.0215 & -0.0601 & -0.0382 & 0.0144 \\
\hline Std dev. & 0.0110 & 0.0147 & -0.0133 & -0.1960 & 0.0069 \\
\hline - Mean value & 0.1583 & 0.0010 & -0.0801 & 0.1185 & 0.0012 \\
\hline Std dev. & 0.0324 & 0.0264 & -0.0428 & -0.3276 & 0.0082 \\
\hline - Mean value & 0.0409 & -0.0123 & -0.0734 & 0.1224 & 0.0197 \\
\hline Std dev. & 0.0323 & 0.0382 & -0.0246 & 2.7953 & 0.0184 \\
\hline - Mean value & 0.1562 & 0.0247 & -0.0702 & 0.0246 & 0.0202 \\
\hline Std dev. & 0.0414 & 0.0200 & -0.0307 & -0.7382 & 0.0214 \\
\hline $\begin{array}{l}\text { Panel J: Kothari, Leone and } \\
\text { Wasley (2005) }\end{array}$ & Intercept & $\begin{array}{l}\Delta \text { SALE- } \\
\Delta \text { REC }\end{array}$ & PPE & ROA-1 & \\
\hline The Czech Republic - Mean value & 0.0166 & 0.0180 & -0.0846 & 1.3544 & \\
\hline Std dev. & 0.0095 & 0.0095 & 0.0164 & 1.5610 & \\
\hline - Mean value & 0.0292 & -0.0023 & -0.0975 & 2.0586 & \\
\hline Std dev. & 0.0130 & 0.0113 & 0.0200 & 2.1098 & \\
\hline - Mean value & 0.0124 & 0.0068 & -0.1055 & 4.5982 & \\
\hline Std dev. & 0.0294 & 0.0274 & 0.0560 & 5.2508 & \\
\hline - Mean value & 0.0323 & -0.0151 & -0.1221 & 7.5836 & \\
\hline Std dev. & 0.0295 & 0.0348 & 0.0459 & 13.2710 & \\
\hline
\end{tabular}

where: $T A_{i t-1}$ - Total Accruals in year $\mathrm{t}-1 ; \triangle R E V_{i t}$ - Annual change in revenues in year $\mathrm{t} ; \triangle R E C_{i t}$ - Annual change in receivables accounts in year $\mathrm{t}$; $P P E_{i t}$ - Gross property, plant and equipment in year t; $E X P_{i t}$ - Operating expenses in year t; $\triangle E X P_{i t}$ - Change in operating expenses excluding non-cash expenses in year t; $C F O_{i t}$ - Cash flow from operations in year $\mathrm{t} ; \triangle C F O_{i t}$ - Change in cash flow from operations in year $\mathrm{t}$; $I A_{i t}$ - Gross intangible assets in year $\mathrm{t} ; \triangle S A L E_{i t}$ - Change in sales in year $\mathrm{t}$; $R O A_{i t-1}$ - Return on assets in year $\mathrm{t}$; $\mathrm{k}$ - is a slope coefficient from regression $\triangle R E C_{i t}$ on $\triangle R E V_{i t}$.

Finally, Table 8 provides summary of the results on the significance of the variables of the models. The results are divided within the panels which correspond to each model. The percentage of the significance is calculated as a relation (division) between the parameters with significance at least at 0.1 to the total number of evaluated years. We have six year period of observation; therefore, the percentage of significance of each variable we calculate by the number of times when the variable is significant divided into six (total of years).

Table 8: Percentage on significance of the variables

\begin{tabular}{|l|l|l|l|l|l|}
\hline Panel A: Jones (1991) & Intercept & $\Delta$ REV & PPE & & \\
\hline The Czech Republic & & $100.00 \%$ & $100.00 \%$ & & \\
\hline Poland & & $66.67 \%$ & $83.33 \%$ & & \\
\hline Hungary & & $66.67 \%$ & $50.00 \%$ & & \\
\hline Slovakia & & $16.67 \%$ & $83.33 \%$ & & \\
\hline mean & & $\mathbf{6 2 . 5 0 \%}$ & $\mathbf{7 9 . 1 7 \%}$ & & \\
\hline $\begin{array}{l}\text { Panel B: Modified Jones } \\
(\mathbf{1 9 9 5})\end{array}$ & Intercept & $\begin{array}{l}\Delta \text { REV- } \\
\text { BREC }\end{array}$ & PPE & & \\
\hline
\end{tabular}




\begin{tabular}{|c|c|c|c|c|c|}
\hline The Czech Republic & & $83.33 \%$ & $100.00 \%$ & & \\
\hline Poland & & $66.67 \%$ & $83.33 \%$ & & \\
\hline Hungary & & $33.33 \%$ & $33.33 \%$ & & \\
\hline Slovakia & & $0.00 \%$ & $83.33 \%$ & & \\
\hline mean & & $45.83 \%$ & $75.00 \%$ & & \\
\hline $\begin{array}{l}\text { Panel C: } \quad \text { Kang } \\
\text { Sivaranakrishnan (1995) }\end{array}$ & Intercept & $\triangle \mathrm{REV}$ & EXP & PPE & \\
\hline The Czech Republic & & $100.00 \%$ & $50.00 \%$ & $100.00 \%$ & \\
\hline Poland & & $100.00 \%$ & $50.00 \%$ & $83.33 \%$ & \\
\hline Hungary & & $33.33 \%$ & $0.00 \%$ & $33.33 \%$ & \\
\hline Slovakia & & $0.00 \%$ & $0.00 \%$ & $83.33 \%$ & \\
\hline mean & & $58.33 \%$ & $25.00 \%$ & $75.00 \%$ & \\
\hline Panel D: Shivakumar (1996) & Intercept & $\triangle \mathrm{REV}$ & PPE & $\mathrm{CFO}$ & \\
\hline The Czech Republic & & $100.00 \%$ & $100.00 \%$ & $66.67 \%$ & \\
\hline Poland & & $50.00 \%$ & $83.33 \%$ & $100.00 \%$ & \\
\hline Hungary & & $66.67 \%$ & $66.67 \%$ & $50.00 \%$ & \\
\hline Slovakia & & $50.00 \%$ & $66.67 \%$ & $0.00 \%$ & \\
\hline mean & & $66.67 \%$ & $79.17 \%$ & $54.17 \%$ & \\
\hline Panel E: Key (1997) & Intercept & $\triangle \mathrm{REV}$ & PPE & IA & \\
\hline The Czech Republic & & $100.00 \%$ & $100.00 \%$ & $33.33 \%$ & \\
\hline Poland & & $83.33 \%$ & $83.33 \%$ & $33.33 \%$ & \\
\hline Hungary & & $66.67 \%$ & $50.00 \%$ & $0.00 \%$ & \\
\hline Slovakia & & $16.67 \%$ & $83.33 \%$ & $0.00 \%$ & \\
\hline mean & & $66.67 \%$ & $79.17 \%$ & $16.67 \%$ & \\
\hline $\begin{array}{l}\text { Panel F: Teoh, Welch and } \\
\text { Wong (1998) }\end{array}$ & Intercept & $\begin{array}{l}\triangle \mathrm{SALE}- \\
\triangle \mathrm{REC}\end{array}$ & & & \\
\hline The Czech Republic & & $50.00 \%$ & & & \\
\hline Poland & & $66.67 \%$ & & & \\
\hline Hungary & & $50.00 \%$ & & & \\
\hline Slovakia & & $0.00 \%$ & & & \\
\hline mean & & $41.67 \%$ & & & \\
\hline Panel G: Kasznik (1999) & Intercept & $\triangle \mathrm{REV}$ & PPE & $\triangle \mathrm{CFO}$ & \\
\hline The Czech Republic & & $100.00 \%$ & $100.00 \%$ & $16.67 \%$ & \\
\hline Poland & & $50.00 \%$ & $83.33 \%$ & $100.00 \%$ & \\
\hline Hungary & & $50.00 \%$ & $66.67 \%$ & $66.67 \%$ & \\
\hline Slovakia & & $16.67 \%$ & $50.00 \%$ & $33.33 \%$ & \\
\hline mean & & $54.17 \%$ & $75.00 \%$ & $54.17 \%$ & \\
\hline $\begin{array}{l}\text { Panel H: Yoon and Miller } \\
(2002)\end{array}$ & Intercept & $\begin{array}{l}\triangle \mathrm{REV}- \\
\triangle \mathrm{REC}\end{array}$ & $\begin{array}{l}\triangle \mathrm{EXP} \\
\triangle \mathrm{PAY}\end{array}$ & \begin{tabular}{|l|} 
NCASH- \\
1xGPPEGRW
\end{tabular} & \\
\hline The Czech Republic & & $100.00 \%$ & $100.00 \%$ & $16.67 \%$ & \\
\hline Poland & & $100.00 \%$ & $100.00 \%$ & $50.00 \%$ & \\
\hline Hungary & & $100.00 \%$ & $100.00 \%$ & $16.67 \%$ & \\
\hline Slovakia & & $100.00 \%$ & $100.00 \%$ & $33.33 \%$ & \\
\hline mean & & $100.00 \%$ & $100.00 \%$ & $29.17 \%$ & \\
\hline Panel I: Dechow. Richardson & Intercept & $(1+\mathrm{k}) \triangle \mathrm{REV}-$ & PPE & TA-1 & $\Delta \mathrm{SALE}+1$ \\
\hline
\end{tabular}




\begin{tabular}{|c|c|c|c|c|c|}
\hline and Tuna (2003) & & $\triangle \mathrm{REC}$ & & & \\
\hline The Czech Republic & & $75.00 \%$ & $100.00 \%$ & $75.00 \%$ & $50.00 \%$ \\
\hline Poland & & $50.00 \%$ & $100.00 \%$ & $50.00 \%$ & $50.00 \%$ \\
\hline Hungary & & $25.00 \%$ & $75.00 \%$ & $50.00 \%$ & $25.00 \%$ \\
\hline Slovakia & & $0.00 \%$ & $75.00 \%$ & $25.00 \%$ & $25.00 \%$ \\
\hline mean & & $37.50 \%$ & $87.50 \%$ & $50.00 \%$ & $37.50 \%$ \\
\hline $\begin{array}{l}\text { Panel J: Kothari, Leone and } \\
\text { Wasley (2005) }\end{array}$ & Intercept & $\begin{array}{l}\triangle \mathrm{SALE}- \\
\triangle \mathrm{REC}\end{array}$ & PPE & ROA-1 & \\
\hline The Czech Republic & & $50.00 \%$ & $100.00 \%$ & $16.67 \%$ & \\
\hline Poland & & $66.67 \%$ & $83.33 \%$ & $33.33 \%$ & \\
\hline Hungary & & $50.00 \%$ & $50.00 \%$ & $33.33 \%$ & \\
\hline Slovakia & & $0.00 \%$ & $83.33 \%$ & $33.33 \%$ & \\
\hline mean & & $41.67 \%$ & $79.17 \%$ & $29.17 \%$ & \\
\hline
\end{tabular}

where: $T A_{i t-1}$ - Total Accruals in year $\mathrm{t}-1 ; \triangle R E V_{i t}$ - Annual change in revenues in year $\mathrm{t} ; \triangle R E C_{i t}$ - Annual change in receivables accounts in year $\mathrm{t}$; $P P E_{i t}$ - Gross property, plant and equipment in year $\mathrm{t}$; $E X P_{i t}$ - Operating expenses in year t; $\triangle E X P_{i t}$ - Change in operating expenses excluding non-cash expenses in year t; $C F O_{i t}$ - Cash flow from operations in year $\mathrm{t} ; \triangle C F O_{i t}$ - Change in cash flow from operations in year $\mathrm{t}$; $I A_{i t}$ - Gross intangible assets in year $\mathrm{t} ; \triangle S A L E_{i t}$ - Change in sales in year $\mathrm{t} ; R O A_{i t-1}$ - Return on assets in year $\mathrm{t}$; $\mathrm{k}$ - is a slope coefficient from regression $\triangle R E C_{i t}$ on $\triangle R E V_{i t}$.

We may observe slightly better results for Jones (1991) and Shivakumar (1996) models. They present high percentage of the significance of almost all variables, exceptions of Slovakia sample shows low or no significance within some of the variables (see for example, no significance for CFO variable of the Shivakumar model, or low significance of $\triangle \mathrm{REV}$ of Jones model). Other countries' samples present very reliable results.

On the other hand, we observe poor results for the Kang and Sivaranakrishnan model (1995), many insignificant variables over the years and within different samples. The results on the Dechow, Richardson and Tuna (2003) model show also that the model is not well specified for the two of the four variables.

\subsection{Time-Series Approach}

The results on adjusted $\mathrm{R}^{2}$ for each model are presented in Table 9 . We may observe that the Yoon and Miller model (2002) shows the highest values of adjusted $\mathrm{R}^{2}$. The values range from $33.55 \%$ for the Czech Republic sample to $41.29 \%$ for the Slovakian sample, obtaining a mean within all countries of $37.96 \%$. It indicates that the Yoon and Miller model (2002) significantly better measures earnings management than other models.

Nevertheless, we detect that within our three of four samples (The Czech Republic, Poland, and Hungary) five of our rest nine models presents very similar and solid results. Jones (1991), Kand and Sivaranakrishnan (1995), Shivakumar (1996), Key (1997) and Kasznik model (1999) report values of adjusted $\mathrm{R}^{2}$, is ranging from $6.7 \%$ to $14.1 \%$. Adjusted $\mathrm{R}^{2}$ for our last sample (Slovakia sample) is almost similar for all models ( $7 \%$ to $10 \%$, with the exception of Teoh et al., 1998). 
Table 9: Evaluation of earnings management measurement models - Adjusted $\mathrm{R}^{2}$

\begin{tabular}{|l|l|l|l|l|l|}
\hline Measurement model & \multicolumn{5}{|l|}{} \\
\hline & The Czech R. & Poland & Hungary & Slovakia & Mean \\
\hline Jones (1991) & 0.0957 & 0.0671 & 0.0937 & 0.0856 & 0.0855 \\
\hline Modified Jones (1995) & 0.0440 & 0.0331 & 0.0357 & 0.0722 & 0.0462 \\
\hline $\begin{array}{l}\text { Kang and Sivaranakrishnan } \\
\text { (1995) }\end{array}$ & 0.0967 & 0.0774 & 0.0921 & 0.0839 & 0.0875 \\
\hline Shivakumar (1996) & 0.0982 & 0.0810 & 0.1295 & 0.0839 & 0.0982 \\
\hline Key (1997) & 0.0968 & 0.0682 & 0.0922 & 0.0839 & 0.0853 \\
\hline Teoh, Welch and Wong (1998) & 0.0117 & 0.0099 & 0.0084 & 0.0000 & 0.0075 \\
\hline Kasznik (1999) & 0.0972 & 0.0777 & 0.1409 & 0.0935 & 0.1023 \\
\hline Yoon and Miller (2002) & 0.3355 & 0.3684 & 0.4018 & 0.4129 & 0.3796 \\
\hline $\begin{array}{l}\text { Dechow, Richardson and Tuna } \\
\text { (2003) }\end{array}$ & 0.0552 & 0.0464 & 0.0568 & 0.1041 & 0.0656 \\
\hline $\begin{array}{l}\text { Kothari, Leone and Wasley } \\
\text { (2005) }\end{array}$ & 0.0340 & 0.0302 & 0.0503 & 0.0754 & 0.0475 \\
\hline
\end{tabular}

Table 10 presents results on predicted sign of the variables. The percentage of the coefficient of a predicted sign (\% Positive) for each model is calculated as a number of times when the variable obtains the expected sign to a total of the observations (we have four samples).

We detect, that for Jones model (1991) all samples for both variables show expected sign, which means that relationship between independent variables with dependent variables have corrected correlations. Moreover, we observe that four other models also show reliable and consistent results on predicted sign: Modified Jones model (1995), Shivakumar model (1996), Key model (1997), and Yoon and Miller model (2002). All these models present high percentage of predicted sign of the coefficient for all variables (in $100 \%$ or $75 \%$ of the regressions have expected sign).

Table 10: Evaluation of earnings management measurement models: predicted sign

\begin{tabular}{|l|l|}
\hline Measurement model: variables and predicted sign & $\begin{array}{l}\% \text { of the predicted sign. It is calculated as a } \\
\text { number of times the variables obtained } \\
\text { expected sign }\end{array}$ \\
\hline Jones (1991) & \\
\hline$\Delta$ REV $(+)$ & $100.00 \%$ \\
\hline PPE $(-)$ & $100.00 \%$ \\
\hline Modified Jones (1995) & \\
\hline$\Delta$ REV- $\Delta$ REC $(+)$ & $75.00 \%$ \\
\hline PPE (-) & $100.00 \%$ \\
\hline Kang and Sivaranakrishnan (1995) & \\
\hline$\Delta$ REV $(+)$ & $100.00 \%$ \\
\hline EXP $(+)$ & $0.00 \%$ \\
\hline
\end{tabular}




\begin{tabular}{|c|c|}
\hline PPE (-) & $100.00 \%$ \\
\hline \multicolumn{2}{|l|}{ Shivakumar (1996) } \\
\hline$\Delta \mathrm{REV}(+)$ & $100.00 \%$ \\
\hline PPE (-) & $100.00 \%$ \\
\hline CFO (-) & $75.00 \%$ \\
\hline \multicolumn{2}{|l|}{ Key (1997) } \\
\hline$\triangle \mathrm{REV}(+)$ & $100.00 \%$ \\
\hline PPE (-) & $100.00 \%$ \\
\hline IA (-) & $75.00 \%$ \\
\hline \multicolumn{2}{|c|}{ Teoh, Welch and Wong (1998) } \\
\hline$\triangle$ SALE- $\triangle$ REC $(+)$ & $75.00 \%$ \\
\hline \multicolumn{2}{|l|}{ Kasznik (1999) } \\
\hline$\triangle \mathrm{REV}(+)$ & $100.00 \%$ \\
\hline PPE (-) & $100.00 \%$ \\
\hline$\triangle \mathrm{CFO}(-)$ & $25.00 \%$ \\
\hline \multicolumn{2}{|l|}{ Yoon and Miller (2002) } \\
\hline$\triangle \mathrm{REV}-\triangle \mathrm{REC}(-)$ & $100.00 \%$ \\
\hline$\Delta \mathrm{EXP}-\triangle \mathrm{PAY}(+)$ & $100.00 \%$ \\
\hline NCASH-1xGPPEGRW (-) & $75.00 \%$ \\
\hline \multicolumn{2}{|c|}{ Dechow, Richardson and Tuna (2003) } \\
\hline$(1+\mathrm{k}) \Delta \mathrm{REV}-\Delta \mathrm{REC}(+)$ & $100.00 \%$ \\
\hline PPE (-) & $100.00 \%$ \\
\hline TA-1 (+) & $0.00 \%$ \\
\hline$\triangle \mathrm{SALE}+1(+)$ & $75.00 \%$ \\
\hline \multicolumn{2}{|c|}{ Kothari, Leone and Wasley (2005) } \\
\hline$\Delta \mathrm{SALE}-\Delta \mathrm{REC}(+)$ & $75.00 \%$ \\
\hline PPE (-) & $100.00 \%$ \\
\hline ROA-1 (+) & $75.00 \%$ \\
\hline
\end{tabular}

where: $T A_{i t-1}$ - Total Accruals in year $\mathrm{t}-1 ; \Delta R E V_{i t}$ - Annual change in revenues in year $\mathrm{t} ; \triangle R E C_{i t}$ - Annual change in receivables accounts in year t; $P P E_{i t}$ - Gross property, plant and equipment in year t; $E X P_{i t}$ - Operating expenses in year t; $\triangle E X P_{i t}$ - Change in operating expenses excluding non-cash expenses in year t; $C F O_{i t}$ - Cash flow from operations in year $\mathrm{t} ; \triangle C F O_{i t}$ - Change in cash flow from operations in year $\mathrm{t}$; $I A_{i t}$ - Gross intangible assets in year $\mathrm{t} ; \triangle S A L E_{i t}$ - Change in sales in year $\mathrm{t} ; R O A_{i t-1}$ - Return on assets in year $\mathrm{t}$; $\mathrm{k}$ - is a slope coefficient from regression $\triangle R E C_{i t}$ on $\triangle R E V_{i t}$.

Other models such as Kang and Sivaranakrishnan (1995) or Dechow, Richardson and Tuna (2003) have one variable which does not show predictive sign of the variables. It means that the variables should be eliminated from the model.

Kasznik model (1999), Teoh et al. model (1998) and Kothari et al. model (2005) indicate in most cases correct relationship between the variables: independents and dependents variables. However in some cases the percentage of the predicted sign is low, for example, third variable, $\Delta \mathrm{CFO}$, of the Kasznik model (1999) present only $25 \%$ of the variables show predicted sign. 
Table 11 provides results on standard deviation and mean values on the variables by the models. The results are divided within the panels which correspond to each model. Jones model (1991) shows significant variability of the standard errors, for example, for the Czech Republic and Poland we observe low standard errors (4\%, 7\% for the Czech Republic respectively for the variables, and $6 \%$ and $9 \%$ for Poland, respectively for revenues and plant, property and equipment variables). On the other hand, for the Hungary and Slovakia we may observe higher standard errors, 16\%, 24\% for Hungary, and 35\% and 15\% for Slovakia.

Following models also show this variability of the results. However, in some cases even within the same sample, the different variables show very different percentage of standard error, which confuse the interpretation, for example, Key model (1997) for the sample of Polish companies, shows $6 \%$ and $9 \%$ of the standard error, for revenues and property, plant and equipment variables respectively. Nevertheless the third variable indicates very high $38 \%$ of the standard error.

Table 11: Results on mean values and standard deviation by models along the samples

\begin{tabular}{|c|c|c|c|c|}
\hline \multirow{2}{*}{\begin{tabular}{|l} 
Panel A: Jones (1991) \\
The Czech Republic - Mean \\
value
\end{tabular}} & Intercept & $\triangle \mathbf{R E V}$ & PPE & \\
\hline & 0.0054 & 0.0635 & -0.0822 & \\
\hline Std dev. & 0.0036 & 0.0028 & 0.0065 & \\
\hline - Mean value & 0.0037 & 0.0605 & -0.0809 & \\
\hline Std dev. & 0.0050 & 0.0038 & 0.0079 & \\
\hline - Mean value & 0.0000 & 0.0609 & -0.0953 & \\
\hline Std dev. & 0.0122 & 0.0098 & 0.0236 & \\
\hline - Mean value & 0.0239 & 0.0345 & -0.1223 & \\
\hline Std dev. & 0.0118 & 0.0123 & 0.0185 & \\
\hline $\begin{array}{l}\text { Panel B: Modified Jones } \\
\text { (1995) }\end{array}$ & Intercept & $\Delta \mathrm{REV}-\Delta \mathrm{REC}$ & PPE & \\
\hline $\begin{array}{l}\text { The Czech Republic - Mean } \\
\text { value }\end{array}$ & 0.0123 & 0.0380 & -0.0808 & \\
\hline Std dev. & 0.0037 & 0.0032 & 0.0066 & \\
\hline - Mean value & 0.0120 & 0.0335 & -0.0839 & \\
\hline Std dev. & 0.0051 & 0.0042 & 0.0080 & \\
\hline - Mean value & 0.0095 & 0.0240 & -0.0969 & \\
\hline Std dev. & 0.0125 & 0.0110 & 0.0243 & \\
\hline - Mean value & 0.0322 & -0.0023 & -0.1236 & \\
\hline Std dev. & 0.0118 & 0.0126 & 0.0186 & \\
\hline $\begin{array}{l}\text { Panel C: Kang and } \\
\text { Sivaranakrishnan (1995) }\end{array}$ & Intercept & $\Delta \mathrm{REV}$ & EXP & PPE \\
\hline $\begin{array}{l}\text { The Czech Republic - Mean } \\
\text { value }\end{array}$ & 0.0177 & 0.0694 & -0.0051 & -0.0906 \\
\hline Std dev. & 0.0056 & 0.0035 & 0.0018 & 0.0071 \\
\hline - Mean value & 0.0426 & \begin{tabular}{|l|}
0.0797 \\
\end{tabular} & -0.0139 & -0.1091 \\
\hline Std dev. & 0.0072 & 0.0045 & 0.0018 & 0.0087 \\
\hline - Mean value & 0.0035 & 0.0624 & -0.0012 & -0.0980 \\
\hline
\end{tabular}




\begin{tabular}{|c|c|c|c|c|c|}
\hline Std dev. & 0.0197 & 0.0118 & 0.0052 & 0.0265 & \\
\hline - Mean value & 0.0244 & 0.0348 & -0.0003 & -0.1226 & \\
\hline Std dev. & 0.0174 & 0.0149 & 0.0066 & 0.0196 & \\
\hline $\begin{array}{l}\text { Panel D: Shivakumar } \\
\text { (1996) }\end{array}$ & Intercept & $\Delta \mathrm{REV}$ & PPE & $\mathrm{CFO}$ & \\
\hline $\begin{array}{l}\text { The Czech Republic - Mean } \\
\text { value }\end{array}$ & 0.0117 & 0.0670 & -0.0798 & -0.0703 & \\
\hline Std dev. & 0.0039 & 0.0030 & 0.0065 & 0.0165 & \\
\hline - Mean value & 0.0195 & 0.0702 & -0.0815 & -0.1441 & \\
\hline Std dev. & 0.0053 & 0.0039 & 0.0078 & 0.0163 & \\
\hline - Mean value & -0.0226 & 0.0522 & -0.1076 & 0.2517 & \\
\hline Std dev. & 0.0128 & 0.0098 & 0.0233 & 0.0533 & \\
\hline - Mean value & 0.0246 & 0.0348 & -0.1220 & -0.0080 & \\
\hline Std dev. & 0.0128 & 0.0125 & 0.0187 & 0.0578 & \\
\hline Panel E: Key (1997) & Intercept & $\Delta \mathrm{REV}$ & PPE & IA & \\
\hline $\begin{array}{l}\text { The Czech Republic - Mean } \\
\text { value }\end{array}$ & 0.0069 & 0.0639 & -0.0814 & -0.1494 & \\
\hline Std dev. & 0.0037 & 0.0028 & 0.0065 & 0.0504 & \\
\hline - Mean value & 0.0053 & 0.0610 & -0.0805 & -0.1300 & \\
\hline Std dev. & 0.0051 & 0.0038 & 0.0079 & 0.0492 & \\
\hline - Mean value & -0.0003 & 0.0607 & -0.0930 & -0.0271 & \\
\hline Std dev. & 0.0122 & 0.0099 & 0.0245 & 0.0785 & \\
\hline - Mean value & 0.0239 & 0.0344 & -0.1226 & 0.0123 & \\
\hline Std dev. & 0.0118 & 0.0123 & 0.0187 & 0.1045 & \\
\hline Panel F: Teoh et al. (1998) & Intercept & $\begin{array}{l}\triangle \text { SALE- } \\
\triangle \text { REC }\end{array}$ & & & \\
\hline $\begin{array}{l}\text { The Czech Republic - Mean } \\
\text { value }\end{array}$ & -0.0238 & 0.0292 & & & \\
\hline Std dev. & 0.0021 & 0.0034 & & & \\
\hline - Mean value & -0.0335 & 0.0308 & & & \\
\hline Std dev. & 0.0026 & 0.0043 & & & \\
\hline - Mean value & -0.0310 & 0.0262 & & & \\
\hline Std dev. & 0.0074 & 0.0113 & & & \\
\hline - Mean value & -0.0344 & -0.0143 & & & \\
\hline Std dev. & 0.0058 & 0.0142 & & & \\
\hline Panel G: Kasznik (1999) & Intercept & $\Delta \mathrm{REV}$ & PPE & $\Delta \mathrm{CFO}$ & \\
\hline $\begin{array}{l}\text { The Czech Republic - Mean } \\
\text { value }\end{array}$ & 0.0058 & 0.0596 & -0.0835 & 0.0750 & \\
\hline Std dev. & 0.0036 & 0.0031 & 0.0065 & 0.0219 & \\
\hline - Mean value & 0.0018 & 0.0700 & -0.0764 & -0.1407 & \\
\hline Std dev. & 0.0050 & 0.0040 & 0.0079 & 0.0182 & \\
\hline - Mean value & 0.0078 & 0.0377 & -0.1068 & 0.4076 & \\
\hline Std dev. & \begin{tabular}{|l|}
0.0119 \\
\end{tabular} & 0.0105 & 0.0231 & 0.0751 & \\
\hline - Mean value & 0.0248 & 0.0280 & -0.1269 & \begin{tabular}{|l|l|}
0.1839 \\
\end{tabular} & \\
\hline Std dev. & \begin{tabular}{|l|}
0.0117 \\
\end{tabular} & 0.0125 & 0.0185 & 0.0772 & \\
\hline
\end{tabular}




\begin{tabular}{|c|c|c|c|c|c|}
\hline $\begin{array}{l}\text { Panel H: Yoon and Miller } \\
(2002)\end{array}$ & Intercept & $\Delta \mathrm{REV}-\Delta \mathrm{REC}$ & $\begin{array}{l}\triangle \mathrm{EXP}- \\
\Delta \mathrm{PAY}\end{array}$ & \begin{tabular}{|l} 
NCASH- \\
1xGPPEGRW
\end{tabular} & \\
\hline $\begin{array}{l}\text { The Czech Republic - Mean } \\
\text { value }\end{array}$ & -0.0338 & -0.5052 & 0.5840 & 0.1214 & \\
\hline Std dev. & 0.0017 & 0.0104 & 0.0109 & 0.0341 & \\
\hline - Mean value & -0.0392 & -0.5967 & 0.6850 & -0.0730 & \\
\hline Std dev. & 0.0021 & 0.0123 & 0.0128 & 0.0662 & \\
\hline - Mean value & -0.0381 & -0.6370 & 0.6954 & -0.4682 & \\
\hline Std dev. & 0.0059 & 0.0370 & 0.0377 & 0.2288 & \\
\hline - Mean value & -0.0471 & -0.5363 & 0.6222 & -0.6132 & \\
\hline Std dev. & 0.0047 & 0.0297 & 0.0322 & 0.1932 & \\
\hline $\begin{array}{l}\text { Panel I: Dechow, } \\
\text { Richardson and Tuna } \\
(\mathbf{2 0 0 3 )}\end{array}$ & Intercept & $\begin{array}{l}(1+\mathrm{k}) \Delta \mathrm{REV}- \\
\Delta \mathrm{REC}\end{array}$ & PPE & TA-1 & $\triangle \mathrm{SALE}+1$ \\
\hline $\begin{array}{l}\text { The Czech Republic - Mean } \\
\text { value }\end{array}$ & 0.0165 & 0.0367 & -0.0878 & -0.0572 & 0.0136 \\
\hline Std dev. & 0.0050 & 0.0033 & 0.0086 & 0.0157 & 0.0049 \\
\hline - Mean value & 0.0517 & 0.0054 & -0.1171 & -0.0605 & -0.0094 \\
\hline Std dev. & 0.0066 & 0.0046 & 0.0093 & 0.0151 & 0.0057 \\
\hline - Mean value & 0.0089 & 0.0125 & -0.1076 & -0.1089 & 0.0161 \\
\hline Std dev. & 0.0134 & 0.0113 & 0.0252 & 0.0400 & 0.0131 \\
\hline - Mean value & 0.0267 & 0.0060 & -0.1282 & -0.0725 & 0.0275 \\
\hline Std dev. & 0.0132 & 0.0140 & 0.0204 & \begin{tabular}{|l|}
0.0479 \\
\end{tabular} & 0.0141 \\
\hline $\begin{array}{l}\text { Panel J: Kothari Leone } \\
\text { and Wasley }(2005)\end{array}$ & Intercept & $\begin{array}{l}\triangle \mathrm{SALE}- \\
\triangle \mathrm{REC}\end{array}$ & PPE & ROA-1 & \\
\hline $\begin{array}{l}\text { The Czech Republic - Mean } \\
\text { value }\end{array}$ & 0.0135 & 0.0295 & -0.0795 & 0.3018 & \\
\hline Std dev. & 0.0038 & 0.0034 & 0.0067 & 0.5699 & \\
\hline - Mean value & 0.0128 & 0.0297 & -0.0840 & -0.0344 & \\
\hline Std dev. & 0.0052 & 0.0042 & 0.0081 & 0.6716 & \\
\hline - Mean value & 0.0052 & 0.0279 & -0.1006 & 6.0370 & \\
\hline Std dev. & 0.0125 & 0.0111 & 0.0242 & 2.0099 & \\
\hline - Mean value & 0.0329 & -0.0177 & -0.1243 & 5.4868 & \\
\hline Std dev. & 0.0119 & 0.0137 & 0.0186 & 4.5932 & \\
\hline
\end{tabular}

where: $T A_{i t-1}$ - Total Accruals in year $\mathrm{t}-1 ; \Delta R E V_{i t}$ - Annual change in revenues in year $\mathrm{t} ; \triangle R E C_{i t}$ - Annual change in receivables accounts in year $\mathrm{t} ; P P E_{i t}$ - Gross property, plant and equipment in year $\mathrm{t}$ EXP $P_{i t}$ - Operating expenses in year $\mathrm{t} ; \triangle E X P_{i t}$ - Change in operating expenses excluding non-cash expenses in year t; $C F O_{i t}$ - Cash flow from operations in year $\mathrm{t} ; \triangle C F O_{i t}$ - Change in cash flow from operations in year $\mathrm{t}$; $I A_{i t}$ - Gross intangible assets in year $\mathrm{t} ; \triangle S A L E_{i t}$ - Change in sales in year $\mathrm{t} ; R O A_{i t-1}$ - Return on assets in year $\mathrm{t}$; $\mathrm{k}$ - is a slope coefficient from regression $\triangle R E C_{i t}$ on $\triangle R E V_{i t}$. Source: The author.

Finally, Table 12 provides summary of the results on the significance of the variables of the models. The results are divided within the panels which correspond to each model. The percentage of the significance is calculated as a relation (division) between the parameters with 
significance at least at 0.1 to the total number of evaluated samples. We have four samples; therefore, the percentage of significance of each variable we calculate by the number of samples when the variable is significant divided into four (total of samples).

The results indicate that five models present solid results within the total of models: Jones model (1991), Modified Jones model (1995), Shivakumar model (1996), Kasznik model (1999) and Yoon and Miller model (2002). We may observe very reliable results of significance of total of the variables of the models at 0.01 levels.

Other models present some of the variables with insignificant relation between the variables, see for example, Dechow, Richardson and Tuna model (2003) shows insignificant first variable, $(1+\mathrm{k}) \triangle \mathrm{REV}-\triangle \mathrm{REC}$, (only 25\%) for three of four our samples. Key model (1997) has insignificant variables for two samples (within four samples) for last variables of the regression, IA. Kang and Sivaranakrishnan model (1995) also confirms low significance for the second variable of the model, EXP, having only $50 \%$ of the significant variables.

Table 12: Percentage on significance of the variables

\begin{tabular}{|c|c|c|c|c|c|}
\hline \multirow[t]{2}{*}{ Panel A: Jones (1991) } & Intercept & $\triangle \mathrm{REV}$ & PPE & & \\
\hline & & $100.00 \%$ & $100.00 \%$ & & \\
\hline \multirow[t]{2}{*}{ Panel B: Modified Jones (1995) } & Intercept & $\Delta \mathrm{REV}-\Delta \mathrm{REC}$ & PPE & & \\
\hline & & $75.00 \%$ & $100.00 \%$ & & \\
\hline \multirow{2}{*}{$\begin{array}{lccc}\text { Panel } & \text { C: } & \text { Kang } & \text { and } \\
\text { Sivaranakrishnan } & (1995) & \\
\end{array}$} & Intercept & $\triangle \mathrm{REV}$ & EXP & PPE & \\
\hline & & $100.00 \%$ & $50.00 \%$ & $100.00 \%$ & \\
\hline \multirow[t]{2}{*}{ Panel D: Shivakumar (1996) } & Intercept & $\triangle \mathrm{REV}$ & $\mathrm{PPE}$ & $\mathrm{CFO}$ & \\
\hline & & $100.00 \%$ & $100.00 \%$ & $75.00 \%$ & \\
\hline \multirow[t]{2}{*}{ Panel E: Key (1997) } & Intercept & $\triangle \mathrm{REV}$ & PPE & IA & \\
\hline & & $100.00 \%$ & $100.00 \%$ & $50.00 \%$ & \\
\hline \multirow[t]{2}{*}{$\begin{array}{l}\text { Panel F: Teoh, Welch and } \\
\text { Wong (1998) }\end{array}$} & Intercept & $\begin{array}{l}\triangle \text { SALE- } \\
\triangle \text { REC }\end{array}$ & & & \\
\hline & & $75.00 \%$ & & & \\
\hline \multirow{2}{*}{ Panel G: Kasznik (1999) } & Intercept & $\triangle \mathrm{REV}$ & $\mathrm{PPE}$ & $\triangle \mathrm{CFO}$ & \\
\hline & & $100.00 \%$ & $100.00 \%$ & $100.00 \%$ & \\
\hline \multirow[t]{2}{*}{$\begin{array}{l}\text { Panel H: Yoon and Miller } \\
(2002)\end{array}$} & Intercept & $\Delta \mathrm{REV}-\Delta \mathrm{REC}$ & $\begin{array}{l}\Delta \mathrm{EXP}- \\
\triangle \mathrm{PAY}\end{array}$ & $\begin{array}{l}\text { NCASH- } \\
\text { 1xGPPEGRW }\end{array}$ & \\
\hline & & $100.00 \%$ & $100.00 \%$ & $75.00 \%$ & \\
\hline \multirow[t]{2}{*}{$\begin{array}{l}\text { Panel I: Dechow, Richardson } \\
\text { and Tuna (2003) }\end{array}$} & Intercept & $\begin{array}{l}(1+\mathrm{k}) \Delta \mathrm{REV}- \\
\Delta \mathrm{REC}\end{array}$ & PPE & TA-1 & $\begin{array}{l}\triangle \mathrm{SALE} \\
+1\end{array}$ \\
\hline & & $25.00 \%$ & $100.00 \%$ & $75.00 \%$ & $75.00 \%$ \\
\hline \multirow[t]{2}{*}{$\begin{array}{l}\text { Panel J: Kothari, Leone and } \\
\text { Wasley (2005) }\end{array}$} & Intercept & $\begin{array}{l}\triangle \mathrm{SALE}- \\
\triangle \mathrm{REC}\end{array}$ & PPE & ROA-1 & \\
\hline & & $75.00 \%$ & $100.00 \%$ & $25.00 \%$ & \\
\hline
\end{tabular}

where: $T A_{i t-1}$ - Total Accruals in year $\mathrm{t}-1 ; \triangle R E V_{i t}$ - Annual change in revenues in year $\mathrm{t} ; \triangle R E C_{i t}$ - Annual change in receivables accounts in year $\mathrm{t}$; $P P E_{i t}$ - Gross property, plant and equipment in year $\mathrm{t}$; $E X P_{i t}$ - Operating expenses in year t; $\triangle E X P_{i t}$ - Change in operating expenses excluding non-cash expenses in year t; $C F O_{i t}$ - Cash 
flow from operations in year $\mathrm{t} ; \triangle C F O_{i t}$ - Change in cash flow from operations in year $\mathrm{t} ; I A_{i t}$ - Gross intangible assets in year $\mathrm{t} ; \triangle S A L E_{i t}$ - Change in sales in year t; $R O A_{i t-1}$ - Return on assets in year $\mathrm{t}$; $\mathrm{k}$ - is a slope coefficient from regression $\triangle R E C_{i t}$ on $\triangle R E V_{i t}$.

\section{Conclusions}

Earnings management has received considerable attention as numerous papers were investigated different hypotheses. However, there is still no consensus on how efficiently detect and measure earnings managements. We may find significant number of models proposed by the literature over the years. Additionally, the earnings management literature confirms that the environment where the company is operating influences on the earnings management. Therefore, the primary objective of this study was to evaluate the ability of the earnings management models for the new developing environment of Eastern European countries. In particular, our analysis focused on four different and independent samples from emerging Eastern European countries: Poland, Hungary, Slovakia and the Czech Republic, since earnings management in Eastern European countries is still barely explored.

Our analyses centred on ten models in detecting earnings management. The empirical results indicate that among different earnings management models, the Jones (1991), Shivakumar (1996), Kasznik (1999) and Yoon and Miller model (2002) offer the most reliable results for detecting earnings management in emerging Eastern European post-communism economic environment. Surprisingly, widely used by the literature modified Jones model (Dechow, Sloan and Sweeney, 1995) is not as reliable as can be expected for our samples of emerging countries. It confirms that application of the most popular five models of discretionary accruals in the Eastern European economic environment shows that these predictive models may not have sufficient explanatory power, and there is a need for previous evaluation of the reliability of such models before theirs applications.

Secondly, little research has been conducted to date that evaluates the effectiveness of crosssectional version of each earnings management models vis-à-vis their time series counterparts. Thus, we compared the cross-sectional and time-series analysis of each of the model for our samples' companies of emerging Eastern European countries. Based on broad analyses the results indicate that there is no superiority of the cross-sectional models vis-à-vis their timeseries counterparts. Both methodologies are consistent in detecting earnings management for Eastern European companies.

Moreover, this investigation represents the first study evaluating models on earnings management based on the sample from the emerging Eastern European countries. Most of the papers published on the earnings management topics are based on the US, Asia or the Western Europe. Earnings management in Eastern Europe is still barely unexplored. As a consequence, analysing methodological aspects of measuring earnings management for new European environment offers new insights for future line of investigations. Our results confirm the importance of the previous evaluation of the ability of each model for detecting earnings management before its application. It is because each economic environment has different peculiarities and circumstances, as observed in case of our developing European countries, which are: countries in a process of transition to a market economy, massive privatization undertaken in 
the absence of the proper institutional infrastructure, lack of transparency, environmental uncertainty, among others (Sutela, 1998; Sucher and Zelenka, 1998; Vellam, 2004; Pekná, 2011; Sobanska and Turzynski, 2011, among others), the use of a common set of models cannot guarantee the robustness of the results within this market.

Finally, within the developing Eastern European countries we do not detect differences between the countries in terms of the robustness of the earnings management models. In contrast, we observe similar results. It confirms that for the four emerging countries we may use the same model to detect earnings management as they show comparable economic environment: they are post-communism, developing and market-oriented economies.

Potential future line of research may include comparative study of earnings management models taking the samples both: from Eastern and Western European countries.

Other future studies may try to find out new proxy for detecting earnings management. We have confirmed that all earnings management models have sufficient weaknesses. New model, much more reliable and accurate in separation of accruals into discretionary and non-discretionary components could be important progress in earnings management investigation.

Another possible research topic may focus on the investigation of the scope of earnings management in Eastern European countries, as we may observe ample literature on Western European, US or Asian samples.

\section{References}

[1] Apellaniz, P. and Labrador, M. (1995). El impacto de la regulación contable en la manipulación del beneficio. Estudio empírico de los efectos del PGC de 1990, Revista Española de Financiación y Contabilidad, 24, 82, 13-40.

[2] Bartov, E., Gul, F., (2000). Discretionary-Accruals Models and Audit Qualifications, the University of Rochester, and the Ninth Annual Conference on Financial Economics and Accounting, 1-41.

[3] Bartov,E., Gul,F., Tsui, J., (2001). Discretionary-accruals models and audit qualifications, Journal of Accounting and Economics, 30, 421-452.

[4] Blalock, H. (1979). Social Statistics, New York: McGraw Hill.

[5] Burgstahler,D., Dichev,I., (1997). Earnings management to avoid earnings decreases and losses, Journal of Accounting and Economics, 24, 99-126.

[6] Burgstahler,D., Hail,L., Leuz,C., (2006). The importance of Reporting Incentives: Earnings Management in European Private and Public Firms, Forthcoming in The Accounting Review.

[7] Chaney, P. and Lewis, C. (1995). Earnings management and firm valuation under asymmetric information, Journal of Corporate Finance, 1, 319-345.

[8] Cormier,D., Martinez,I., (2006). The association between management earnings forecasts, earnings management, and stock market valuation: Evidence from French IPOs, The International Journal of Accounting, 41, 209-236.

[9] Darrough, M., Pourjalali, H. and Saudagaran, S. (1998). Earnings Management in Japanese Companies, The International Journal of Accounting, 33, (3), 313-334.

[10] DeAngelo, L., (1986). Accounting numbers as market valuation substitutes: a study of management buyouts of public stockholders, The Accounting Review, 3, 400-420. 
[11] Dechow, P. and Dichev, I. (2002). The quality of accruals and earnings: The role of accrual estimation errors, The Accounting Review, 77 (Supplement), 35-59.

[12] Dechow,P., Richardson, S., Tuna, I., (2003). Why are earnings kinky? An examination of the earnings management explanation, Review of Accounting Studies, 8, 355-384.

[13] Dechow,P., Sloan,R., Sweeney,A., (1995). Detecting Earnings Management, The Accounting Review, 70, (2), 193-225.

[14] DeFond, M., and Subramanyam, K. (1998). Auditor changes and discretionary accruals, Journal of Accounting and Economics, 25, 35-67.

[15] Degeorge, F., Patel, J., and Zeckhauser, R. (1999). Earnings management to exceed thresholds, Journal of Business, vol. 72, 1, 1-33.

[16] Ebrahim, A., (2001). Auditing Quality, Auditor Tenure, Client Importance, and Earnings Management: An Additional Evidence, Rutgers University, working paper, 1-20.

[17] Greene, W. (2002). Econometric Analysis, Prentice Hall, New Jersey, 1-983.

[18] Guay, W., Kothari, S., and Watts, R. (1996). A market based evaluation of discretionary accruals models, Journal of Accounting Research, Vol. 34, 83-105.

[19] Healy, P., (1985). The Effect of Bonus Schemes on Accounting Decisions, Journal of Accounfing and Economics, 7: 85-107.

[20] Healy, P.M., Wahlen, J.M., (1999). A review of the earnings management literature and its implications for standard setting. Accounting Horizons 13 (4), 365-383.

[21] Jaggi,B., Leung,S., (2007). Impact of family dominance on monitoring of earnings management by audit committees: Evidence from Hong Kong, Journal of International Accounting, Auditing and Taxation, 16, 27-50.

[22] Jeanjean, T., (2000). Corporate governance and Earnings Management, CEREG, University of Paris-Dauphine, France, working paper, 1-32.

[23] Jeter, D., Shivakumar, L., (1999). Cross-sectional estimation of abnormal accruals using qquarterly and annual data: Effectiveness in Detecting Event-Specific Earnings Management, Accounting and Business Research 29, 4, 1-47.

[24] Jones, J., (1991). Earnings Management during Import Relief Investigations, Journal of Accounting Research, 29,(2), 193-228.

[25] Kallunki, J., Martikainen, M., (1999). Do Firms Use Industry-Wide Targets When Managing Earnings? Finnish Evidence, The International Journal of Accounting, 34, (2), 249-259.

[26] Kang, S., and Sivaramakrishnan, K. (1995). Issues in testing earnings management and an instrumental variable approach, Journal of Accounting Research, 353-367.

[27] Kaplan, R. (1985). Comments on Paul Healy: Evidence on the effect of bonus schemes on accounting procedures and accrual decisions, Journal of Accounting and Economics, 7, 109-113.

[28] Kasznik, R. (1999). On the association between voluntary disclosure and earnings management. Journal of Accounting Research, 37, 57-81.

[29] Kerstein, J. and Rai, A. (2007). Intra-year shifts in the earnings distribution and their implications for earnings management, Journal of Accounting and Economics 44, 399-419.

[30] Key,K., (1997). Political cost incentives for earnings management in the cable television industry, Journal of Accounting and Economics, 23, 309-337.

[31] Koh,P., (2007). Institutional investor type, earnings management and benchmark beaters, Journal of Accounting and Public Policy, 26, 267-299.

[32] Konings, J., Labro, E., Roodhooft, F., (1998). Earnings Management and trade union activity: results for Belgium, ONDERZOEKSRAPPORT, 9828, 1-23.

[33] Kothari,S., Leone,A., Wasley, C., (2005). Performance matched discretionary accrual measures, Journal of Accounting and Economics, 39, 163-197.

[34] Larcker,D., and Richardson,S., (2004). Fees paid to audit firms, accrual choices, and corporate governance, Journal of Accounting Research, 42, 625-658.

[35] Lo, K., (2008). Earnings management and earnings quality, Journal of Accounting and Economics, 45, 350-357. 
[36] Matis, D., et al. (2010). Jones, Dechow and Kasznik models significance in the Romanian economic environment, Annales Universitatis Apulensis Series Oeconomica, 12, 1, 1-14.

[37] McNichols, M., Wilson, P., (1988). Evidence of Earnings Management from the Provision for Bad Debts, Journal of Accounting Research Vol. 26, 1-32.

[38] McNichols, M., (2000). Research design issues in earnings management studies, Journal of Accounting and Public Policy, 19, 313-345.

[39] Mora, A., Sabater, A., (2008). Evidence of income-decreasing earnings management before labour negotiations within firms, Investigaciones Económicas, 32, 2, 201-230.

[40] Myers, J., Myers, L, and Skinner, D. (2006). Earnings Momentum and Earnings Management, University of Chicago Graduate School of Business, working paper, 1-49.

[41] Neter, J., Wasserman, W., and Whitmore, G. (1993). Applied Statistics, Fourth Edition. Boston: Allyn and Bacon.

[42] Othman, H., Zeghal, D., (2006). A study of earnings-management motives in the AngloAmerican and Euro-Continental accounting models: The Canadian and French cases, The International Journal of Accounting, 41, 406-435.

[43] Park, M., Ro, B., (2004). The effect of firm-industry earnings correlation and announcement timing on firms' accrual decisions, The British Accounting Review, 36, 269-289.

[44] Park,Y., and Shin, H. (2004). Board composition and earnings management in Canada, Journal of Corporate Finance, 10, 431- 457.

[45] Peasnell, K., Pope, P., Young, S., (1999). Detecting Earnings Management Using Cross-Sectional Abnormal Accruals Models, Lancaster University, paper work, 1-33.

[46] Petroni, K. (1992). Optimistic reporting in the property-casualty insurance industry, Journal of Accounting and Economics 15 (4), 485-508.

[47] Praag, van B. (2001). Earnings Management: Empirical Evidence on value relevance and Income smoothing, Dissertation, Faculty of Economics and Business, University of Amsterdam.

[48] Rangan, S., (1998). Earnings management and the performance of seasoned equity offerings, Journal of Financial Economics, 50, 101-122.

[49] Roychowdhury, S., (2006). Earnings management through real activities manipulation, Journal of Accounting and Economics, 42, 335-370.

[50] Schipper, K. (1989). Commentary on earnings management, Accounting Horizons, 3(4), 91-102.

[51] Seok Park,M., Park,T., (2004). Insider sales and earnings management, Journal of Accounting and Public Policy, 23, 381-411.

[52] Shivakumar, L. (1996). Estimating abnormal accruals for detection of earnings management, working paper, Vanderbilt University, March.

[53] Siregar, S., Utama, S., (2008). Type of earnings management and the effect of ownership structure, firm size, and corporate-governance practices: Evidence from Indonesia, The International Journal of Accounting, 43, 1-27.

[54] Snedecor, G., and Cochran, W. (1980). Statistical Methods, 7th Edition. Ames, IA: Iowa State University Press.

[55] Sobanska, I. and Turzynski, M. (2011). Rachunkowość, audyt i kontrola w zarządzaniu, Wydawnictwo Uniwersytetu Łódzkiego.

[56] Subramanyam, K. (1996). The pricing of discretionary accruals, Journal of Accounting and Economics, Vol. 22, 249-281.

[57] Sucher, P. and Zelenka, I. (1998). The Development of the Role of the Audit in the Czech Republic, European Accounting Review, Vol. 7, Iss. 4, 723-751.

[58] Sutela, P. (1998). Privatization in the Countries of Eastern and Central Europe and of the Former Soviet Union, WIDER, World Institute for Development Economics Research, working paper No. 146, 1-67.

[59] Teoh, S., Wong, I., Wong, T., (1998). Earnings management and the underperformance of seasoned equity offerings, Journal of Financial Economics, 50, 63-99. 
[60] Vellam, I. (2004). Implementation of International Accounting Standards in Poland: Can true convergence be achieved in practice?, Accounting in Europe, 1, 143-167.

[61] Weisberg, S. (1985). Applied Linear Regression, 2nd Edition. New York: Wiley.

[62] White, H. (1980). A heteroskedasticity-consistent covariance matrix estimator and a direct test for heteroskedasticity. Econometrica 48, 817-838.

[63] Ye, J., (2007). Accounting Accruals and Tests of Earnings Management, Baruch College, 1-45.

[64] Yoon,S., Miller,G., (2002). Earnings management of seasoned equity offering firms in Korea, The International Journal of Accounting, 37, 57-78.

[65] Zhang, H., (2002). Detecting Earnings Management-Evidence from Rounding-up in Reported EPS, University of Illinois at Chicago, 1-47.

Annex 1: Sample descriptive data

\begin{tabular}{|c|c|c|c|c|c|c|}
\hline & \multicolumn{6}{|l|}{ Years } \\
\hline & 2003 & 2004 & 2005 & 2006 & 2007 & 2008 \\
\hline \multicolumn{7}{|c|}{ PANEL A: THE CZECH REPUBLIC } \\
\hline \multicolumn{7}{|c|}{ Total assets } \\
\hline Mean & 1.0879 & 1.2154 & 1.2231 & 1.2016 & 1.2517 & 1.0412 \\
\hline Std. dev. & 0.2093 & 0.4957 & 0.5445 & 0.3329 & 0.6959 & 0.2131 \\
\hline Median & 1.0556 & 1.1231 & 1.1462 & 1.1601 & 1.1476 & 1.0334 \\
\hline \multicolumn{7}{|c|}{ Property, plant and equipment } \\
\hline Mean & 0.4713 & 0.5069 & 0.4829 & 0.4803 & 0.4612 & 0.4317 \\
\hline Std. dev. & 0.3044 & 0.3159 & 0.2971 & 0.2821 & 0.2737 & 0.2682 \\
\hline Median & 0.4470 & 0.4760 & 0.4604 & 0.4622 & 0.4469 & 0.4218 \\
\hline \multicolumn{7}{|c|}{ Intangible assets } \\
\hline Mean & 0.0142 & 0.0153 & 0.0130 & 0.0126 & 0.0112 & 0.0096 \\
\hline Std. dev. & 0.0376 & 0.0517 & 0.0319 & 0.0351 & 0.0335 & 0.0305 \\
\hline Median & 0.0042 & 0.0045 & 0.0046 & 0.0041 & 0.0035 & 0.0027 \\
\hline \multicolumn{7}{|c|}{ Revenues } \\
\hline Mean & 1.8722 & 2.1886 & 2.0480 & 2.0961 & 2.0668 & 1.8445 \\
\hline Std. dev. & 1.3060 & 1.7327 & 1.4439 & 1.4246 & 1.3971 & 1.2320 \\
\hline Median & 1.5950 & 1.8618 & 1.7908 & 1.8192 & 1.7649 & 1.6137 \\
\hline \multicolumn{7}{|c|}{ Cash Flow from operations } \\
\hline Mean & 0.1081 & 0.1290 & 0.1215 & 0.1265 & 0.1253 & 0.0966 \\
\hline Std. dev. & 0.1145 & 0.1249 & 0.1263 & 0.1167 & 0.1170 & 0.1140 \\
\hline Median & 0.0898 & 0.1079 & 0.1024 & 0.1091 & 0.1064 & 0.0829 \\
\hline \multicolumn{7}{|c|}{ Accounts receivable } \\
\hline Mean & 0.1930 & 0.2380 & 0.1990 & 0.2546 & 0.2695 & 0.2301 \\
\hline Std. dev. & 0.2067 & 0.2816 & 0.2325 & 0.2597 & 0.2209 & 0.1946 \\
\hline Median & 0.1529 & 0.1903 & 0.1410 & 0.2062 & 0.2247 & 0.1867 \\
\hline \multicolumn{7}{|c|}{ Accounts payable } \\
\hline Mean & 0.1824 & 0.2082 & 0.1631 & 0.2143 & 0.2163 & 0.1820 \\
\hline Std. dev. & 0.2209 & 0.2692 & 0.2038 & 0.2366 & 0.1946 & 0.1692 \\
\hline Median & 0.1150 & 0.1305 & 0.0961 & 0.1518 & 0.1621 & 0.1286 \\
\hline \multicolumn{7}{|l|}{ Sales } \\
\hline Mean & 1.7640 & 2.0626 & 1.9316 & 1.9703 & 1.9507 & 1.7401 \\
\hline Std. dev. & 1.2679 & 1.6769 & 1.4027 & 1.3950 & 1.3513 & 1.1943 \\
\hline Median & 1.5125 & 1.7506 & 1.6871 & 1.7120 & 1.6525 & 1.5194 \\
\hline
\end{tabular}




\begin{tabular}{|c|c|c|c|c|c|c|}
\hline Mean & 1.7862 & 2.0812 & 1.9515 & $\mid 1.9941$ & $\mid 1.9661$ & 1.7744 \\
\hline Std. dev. & 1.2813 & 1.6988 & 1.4073 & 1.3981 & 1.3672 & 1.2149 \\
\hline Median & 1.4931 & 1.7346 & 1.6629 & 1.7407 & 1.6694 & 1.5328 \\
\hline \multicolumn{7}{|c|}{\begin{tabular}{|l} 
Non-cash expenses \\
\end{tabular}} \\
\hline Mean & 0.0551 & 0.0608 & 0.0581 & 0.0567 & 0.0545 & 0.0493 \\
\hline Std. dev. & 0.0514 & 0.0598 & 0.0535 & 0.0507 & 0.0489 & 0.0412 \\
\hline Median & 0.0454 & 0.0493 & 0.0485 & 0.0482 & 0.0464 & 0.0428 \\
\hline \multicolumn{7}{|l|}{ ROA } \\
\hline Mean & 4.5649 & 5.4318 & 5.0274 & 5.6464 & 5.8679 & 4.0903 \\
\hline Std. dev. & 9.2815 & 8.3892 & 8.9170 & 8.9314 & 8.9387 & 11.1178 \\
\hline \multirow[t]{3}{*}{ Median } & 3.5347 & 4.0218 & 3.8975 & 4.2646 & 4.7353 & 3.3035 \\
\hline & Years & & & & & \\
\hline & 2003 & 2004 & 2005 & 2006 & 2007 & 2008 \\
\hline \multicolumn{7}{|c|}{ PANEL B: POLAND } \\
\hline \multicolumn{7}{|c|}{ Total assets } \\
\hline Mean & 1.0897 & 1.3675 & 1.1345 & 1.1745 & 1.2431 & 0.9929 \\
\hline Std. dev. & 0.4478 & 0.4693 & 0.2125 & 0.2752 & 0.2167 & 0.2496 \\
\hline Median & 0.9728 & 1.2517 & 1.1066 & 1.1323 & 1.2184 & 0.9513 \\
\hline \multicolumn{7}{|c|}{ Property, plant and equipment } \\
\hline Mean & 0.4756 & 0.6343 & 0.5793 & 0.5571 & 0.5777 & 0.4723 \\
\hline Std. dev. & 0.2395 & 0.3284 & 0.3145 & 0.3224 & 0.3147 & 0.2698 \\
\hline Median & 0.4802 & 0.6354 & 0.5797 & 0.5461 & 0.5812 & 0.4624 \\
\hline \multicolumn{7}{|c|}{ Intangible assets } \\
\hline Mean & 0.0159 & 0.0186 & 0.0153 & 0.0141 & 0.0129 & 0.0107 \\
\hline Std. dev. & 0.0486 & 0.0574 & 0.0498 & 0.0503 & 0.0408 & 0.0448 \\
\hline Median & 0.0026 & 0.0030 & 0.0025 & 0.0022 & 0.0021 & 0.0016 \\
\hline \multicolumn{7}{|c|}{ Revenues } \\
\hline Mean & 1.8151 & 2.4636 & 2.1114 & 2.0467 & 2.1882 & 1.7223 \\
\hline Std. dev. & 1.5296 & 2.0520 & 1.7213 & 1.7695 & 1.7243 & 1.4010 \\
\hline Median & 1.3914 & 1.9599 & 1.7134 & 1.6915 & 1.8571 & 1.4603 \\
\hline \multicolumn{7}{|c|}{ Cash Flow from operations } \\
\hline Mean & 0.0895 & 0.1524 & 0.1241 & 0.1271 & 0.1455 & 0.0930 \\
\hline Std. dev. & 0.2087 & 0.1684 & 0.1262 & 0.1245 & 0.1427 & 0.1139 \\
\hline Median & 0.0715 & 0.1179 & 0.1008 & 0.1037 & 0.1188 & 0.0803 \\
\hline \multicolumn{7}{|c|}{ Accounts receivable } \\
\hline Mean & 0.2543 & 0.3115 & 0.2864 & 0.2759 & 0.2777 & 0.2192 \\
\hline Std. dev. & 0.2327 & 0.2674 & 0.2882 & 0.2246 & 0.2280 & 0.1893 \\
\hline Median & 0.1893 & 0.2491 & 0.2229 & 0.2260 & \begin{tabular}{|l|}
0.2160 \\
\end{tabular} & 0.1708 \\
\hline \multicolumn{7}{|c|}{ Accounts payable } \\
\hline Mean & 0.2214 & 0.2554 & 0.2264 & 0.2189 & 0.2162 & 0.1726 \\
\hline Std. dev. & 0.2436 & 0.2643 & 0.2357 & 0.2385 & 0.2230 & 0.2010 \\
\hline Median & 0.1343 & 0.1683 & 0.1479 & 0.1528 & \begin{tabular}{|l|}
0.1441 \\
\end{tabular} & 0.1081 \\
\hline \multicolumn{7}{|l|}{ Sales } \\
\hline Mean & \begin{tabular}{|l|}
1.7782 \\
\end{tabular} & 2.4179 & 2.0702 & 2.0049 & 2.1433 & 1.6863 \\
\hline Std. dev. & 1.5292 & 2.0557 & 1.7194 & 1.7676 & \begin{tabular}{|l|}
1.7273 \\
\end{tabular} & 1.3970 \\
\hline Median & \begin{tabular}{|l|}
1.3722 \\
\end{tabular} & 1.9156 & 1.6964 & 1.6673 & \begin{tabular}{|l|}
1.8077 \\
\end{tabular} & 1.4350 \\
\hline \multicolumn{7}{|c|}{ Operating expenses } \\
\hline
\end{tabular}




\begin{tabular}{|l|l|l|l|l|l|l|} 
Mean & 1.7477 & 2.3597 & 2.0292 & 1.9575 & 2.0839 & 1.6520 \\
\hline Std. dev. & 1.5008 & 2.0093 & 1.6991 & 1.7501 & 1.6926 & 1.3863 \\
\hline Median & 1.3312 & 1.8508 & 1.6528 & 1.6095 & 1.7432 & 1.3696 \\
\hline Non-cash expenses \\
\hline Mean & 0.0586 & 0.0694 & 0.0618 & 0.0571 & 0.0585 & 0.0469 \\
\hline Std. dev. & 0.1702 & 0.0450 & 0.0411 & 0.0377 & 0.0402 & 0.0314 \\
\hline Median & 0.0468 & 0.0620 & 0.0546 & 0.0518 & 0.0528 & 0.0431 \\
\hline ROA & 2.6949 & 5.9123 & 4.9727 & 5.8613 & 6.7567 & 4.2390 \\
\hline Mean & 11.1548 & 11.0212 & 9.8734 & 9.8279 & 10.7685 & 12.7293 \\
\hline Std. dev. & 1.9278 & 4.2475 & 3.2585 & 4.1575 & 5.0268 & 3.5888 \\
\hline Median &
\end{tabular}

\begin{tabular}{|c|c|c|c|c|c|c|}
\hline & \multicolumn{6}{|l|}{ Years } \\
\hline & 2003 & 2004 & 2005 & 2006 & 2007 & 2008 \\
\hline \multicolumn{7}{|c|}{ PANEL C: HUNGARY } \\
\hline \multicolumn{7}{|c|}{ Total assets } \\
\hline Mean & 1.1216 & 1.1993 & 1.0529 & 1.1324 & 1.1125 & 1.0169 \\
\hline Std. dev. & 0.4360 & 0.3384 & 0.2437 & 0.1902 & 0.2233 & 0.1930 \\
\hline Median & 1.0484 & 1.1332 & 1.0126 & 1.0873 & 1.0840 & 0.9979 \\
\hline \multicolumn{7}{|c|}{ Property, plant and equipment } \\
\hline Mean & 0.4155 & 0.4849 & 0.4117 & 0.4126 & 0.3964 & 0.3680 \\
\hline Std. dev. & 0.2809 & 0.3486 & 0.2777 & 0.2841 & 0.2774 & 0.2595 \\
\hline Median & 0.3933 & 0.4058 & 0.3540 & 0.3617 & 0.3174 & 0.3319 \\
\hline \multicolumn{7}{|c|}{ Intangible assets } \\
\hline Mean & 0.0212 & 0.0350 & 0.0255 & 0.0248 & 0.0230 & 0.0184 \\
\hline Std. dev. & 0.0751 & 0.1371 & 0.0861 & 0.0842 & 0.0813 & 0.0637 \\
\hline Median & 0.0042 & 0.0037 & 0.0041 & 0.0035 & 0.0032 & 0.0025 \\
\hline \multicolumn{7}{|l|}{ Revenues } \\
\hline Mean & 2.2884 & 2.4630 & 2.2477 & 2.5050 & 2.3911 & 2.3138 \\
\hline Std. dev. & 1.5386 & 1.6305 & 1.6154 & 1.8648 & 1.8345 & 1.8605 \\
\hline Median & 1.8859 & 2.0931 & 1.8328 & 2.1015 & 2.0173 & 1.8537 \\
\hline \multicolumn{7}{|c|}{\begin{tabular}{|l|} 
Cash Flow from operations \\
\end{tabular}} \\
\hline Mean & 0.1487 & 0.1490 & 0.1096 & 0.1222 & 0.1072 & 0.0696 \\
\hline Std. dev. & 0.1518 & 0.1390 & 0.1245 & 0.1175 & 0.1002 & 0.1196 \\
\hline Median & 0.1171 & 0.1231 & 0.1062 & 0.1085 & 0.0991 & 0.0731 \\
\hline \multicolumn{7}{|c|}{ Accounts receivable } \\
\hline Mean & 0.2911 & 0.2709 & 0.2657 & 0.2776 & 0.2572 & 0.2206 \\
\hline Std. dev. & 0.3616 & 0.2170 & 0.2262 & 0.2150 & 0.1876 & 0.1677 \\
\hline Median & 0.1834 & 0.2169 & 0.2441 & 0.2499 & 0.2194 & 0.1759 \\
\hline \multicolumn{7}{|c|}{ Accounts payable } \\
\hline Mean & 0.2099 & 0.1904 & 0.1828 & 0.1891 & 0.1796 & 0.1529 \\
\hline Std. dev. & 0.2362 & 0.2099 & 0.1975 & 0.1701 & 0.1726 & 0.1637 \\
\hline Median & 0.1214 & 0.1253 & 0.1279 & 0.1249 & 0.1319 & 0.1046 \\
\hline \multicolumn{7}{|l|}{ Sales } \\
\hline Mean & 2.2117 & 2.3837 & 2.1795 & 2.4293 & 2.3192 & 2.2425 \\
\hline Std. dev. & 1.5257 & 1.6245 & 1.6084 & 1.8444 & 1.8017 & 1.8566 \\
\hline Median & 1.7965 & 2.0101 & 1.7609 & 2.0636 & 1.9347 & 1.8358 \\
\hline
\end{tabular}




\begin{tabular}{|l|l|l|l|l|l|l|} 
Mean & 2.1654 & 2.3609 & 2.1773 & 2.4230 & 2.3233 & 2.2696 \\
\hline Std. dev. & 1.4981 & 1.6140 & 1.6096 & 1.8619 & 1.8443 & 1.8687 \\
\hline Median & 1.7358 & 2.0537 & 1.7194 & 2.0003 & 1.9790 & 1.8329 \\
\hline Non-cash expenses & 0.0577 & 0.0616 & 0.0550 & 0.0569 & 0.0531 & 0.0478 \\
\hline Mean & 0.0410 & 0.0413 & 0.0308 & 0.0338 & 0.0346 & 0.0332 \\
\hline Std. dev. & 0.0485 & 0.0512 & 0.0506 & 0.0511 & 0.0442 & 0.0389 \\
\hline Median & 7.3785 & 6.8728 & 4.7479 & 5.4688 & 4.8654 & 1.9250 \\
\hline ROA & 9.2623 & 10.5945 & 14.1138 & 9.7379 & 8.8942 & 11.8040 \\
\hline Mean & 6.6033 & 5.7174 & 4.1843 & 4.4343 & 4.0162 & 2.0651 \\
\hline Std. dev. & \multicolumn{7}{|l}{} \\
\hline Median
\end{tabular}

\begin{tabular}{|c|c|c|c|c|c|c|}
\hline & \multicolumn{6}{|l|}{ Years } \\
\hline & 2003 & 2004 & 2005 & 2006 & 2007 & 2008 \\
\hline \multicolumn{7}{|c|}{ PANEL D: SLOVAKIA } \\
\hline \multicolumn{7}{|c|}{ Total assets } \\
\hline Mean & 1.0664 & 1.1970 & 1.1420 & 1.1787 & 1.0835 & 1.1564 \\
\hline Std. dev. & 0.2178 & 0.2469 & 0.2619 & 0.2022 & 0.1364 & 0.2245 \\
\hline Median & 1.0304 & 1.1047 & 1.1190 & 1.1538 & 1.0610 & 1.1537 \\
\hline \multicolumn{7}{|c|}{ Property, plant and equipment } \\
\hline Mean & 0.5135 & 0.5917 & 0.5602 & 0.5909 & 0.5152 & 0.5574 \\
\hline Std. dev. & 0.2577 & 0.2984 & 0.2799 & 0.2986 & 0.2163 & 0.2747 \\
\hline Median & 0.4949 & 0.5756 & 0.5107 & 0.5582 & 0.5058 & 0.5554 \\
\hline \multicolumn{7}{|c|}{ Intangible assets } \\
\hline Mean & 0.0156 & 0.0163 & 0.0144 & 0.0130 & 0.0112 & 0.0122 \\
\hline Std. dev. & 0.0541 & 0.0554 & 0.0511 & 0.0475 & 0.0369 & 0.0464 \\
\hline Median & 0.0042 & 0.0042 & 0.0039 & 0.0046 & 0.0033 & 0.0030 \\
\hline \multicolumn{7}{|l|}{ Revenues } \\
\hline Mean & 1.6510 & 1.7797 & 1.6836 & 1.7958 & 1.6569 & 1.7820 \\
\hline Std. dev. & 0.9272 & 0.9737 & 0.9041 & 1.0102 & 0.9691 & 1.1538 \\
\hline Median & 1.4920 & 1.6179 & 1.4706 & 1.6256 & 1.5080 & 1.5564 \\
\hline \multicolumn{7}{|c|}{ Cash Flow from operations } \\
\hline Mean & 0.1090 & 0.1256 & 0.1220 & 0.1184 & 0.1123 & 0.1111 \\
\hline Std. dev. & 0.0964 & 0.1008 & 0.0815 & 0.0821 & 0.0801 & 0.0948 \\
\hline Median & 0.0925 & 0.1080 & 0.1156 & 0.1188 & 0.1031 & 0.1012 \\
\hline \multicolumn{7}{|c|}{ Accounts receivable } \\
\hline Mean & 0.2303 & 0.2388 & 0.2506 & 0.2451 & 0.2380 & 0.2166 \\
\hline Std. dev. & 0.1973 & 0.1981 & 0.2264 & 0.1968 & 0.1906 & 0.1700 \\
\hline Median & 0.1802 & 0.1965 & 0.2118 & 0.2110 & 0.1928 & 0.1926 \\
\hline \multicolumn{7}{|c|}{ Accounts payable } \\
\hline Mean & 0.2253 & 0.2353 & 0.2297 & 0.2305 & 0.2085 & 0.1928 \\
\hline Std. dev. & 0.1964 & 0.1941 & 0.1825 & 0.1740 & 0.1736 & 0.2064 \\
\hline Median & 0.1788 & 0.1960 & 0.2033 & 0.2103 & 0.1548 & 0.1321 \\
\hline \multicolumn{7}{|l|}{ Sales } \\
\hline Mean & 1.6204 & 1.7315 & 1.6496 & 1.7491 & 1.6181 & 1.7386 \\
\hline Std. dev. & 0.9265 & 0.9581 & 0.9054 & 0.9865 & 0.9634 & 1.1296 \\
\hline Median & 1.4698 & 1.5324 & 1.4150 & 1.5741 & 1.4233 & 1.5072 \\
\hline
\end{tabular}




\begin{tabular}{|l|l|l|l|l|l|l|} 
Mean & 1.5764 & 1.6960 & 1.6071 & 1.7313 & 1.5906 & 1.7333 \\
\hline Std. dev. & 0.8894 & 0.9584 & 0.8976 & 1.0022 & 0.9401 & 1.1396 \\
\hline Median & 1.4037 & 1.4918 & 1.3439 & 1.5286 & 1.4223 & 1.5201 \\
\hline Non-cash expenses \\
\hline Mean & 0.0654 & 0.0707 & 0.0662 & 0.0710 & 0.0664 & 0.0722 \\
\hline Std. dev. & 0.0367 & 0.0403 & 0.0363 & 0.0398 & 0.0378 & 0.0400 \\
\hline Median & 0.0613 & 0.0625 & 0.0608 & 0.0668 & 0.0589 & 0.0663 \\
\hline ROA & 3.6874 & 4.3915 & 4.5125 & 3.8946 & 4.0164 & 3.2168 \\
\hline Mean & 7.8892 & 7.4301 & 5.7786 & 7.0059 & 5.9710 & 7.8191 \\
\hline Std. dev. & 2.5893 & 3.0426 & 3.2277 & 3.4713 & 3.0386 & 2.3781 \\
\hline Median
\end{tabular}

All variables scaled by total lagged assets.

\footnotetext{
*Corresponding author.

E-mail address: david.wroblewski@ cretateologia.es/ jijarne@ unizar.es/ scallao@ unizar.es
} 